\title{
Scale Implications for Environmental Risk Assessment and Monitoring of the Cultivation of Genetically Modified Herbicide-Resistant Sugar Beet: A Review
}

\author{
Frieder Graef ${ }^{1,2}$, Gesine Schütte ${ }^{3}$, Birgit Winkel ${ }^{2}$, \\ Hanka Teichmann ${ }^{2}$ and Martha Mertens ${ }^{4}$
}

Accepted on 27 July 2010

Published on 18 September 2010

1 Leibniz Centre for Agricultural Landscape Research (ZALF), Müncheberg, Germany; e-mail: Graef@zalf.de

2 Federal Agency for Nature Conservation (BfN), Bonn, Germany

3 FSP BIOGUM, Hamburg University, Hamburg, Germany

4 Institute for Biodiversity - Network, Regensburg, Germany

\begin{abstract}
Genetically modified herbicide-resistant (GMHR) sugar beet (Beta vulgaris L.) has been cultivated in the US for several years and an application has been submitted for cultivation in Europe. Concerns have been raised about how GMHR sugar beet cultivation might impair the agro-environment.

European legislation for GM plants requires, prior to their commercial import and/or cultivation, a stepwise reduction of the containment and a gradual increase in the scale of release. Experimental results gained during this procedure enter an environmental risk assessment; after the GM plant approval, a systematic monitoring of potential adverse environmental effects is required.

We collected information on sugar beet biology and cultivation and the HR technology. We categorised the literature findings, evaluated the evidence of agro-environmental effects and indicated adverse effects. The impacts are directly and indirectly linked to sugar beet biology and/or to the HR technology. Most likely are a) adverse herbicide effects on field organisms, aquatic communities and soil microbial communities, b) persistence of the GM plant triggered by a potential selective advantage and/or genetic drift after hybridisation of GMHR cultivated, feral and weed beet with neighbouring beets and wild relatives, c) the increase of HR in weeds and subsequent increase and/or change in the herbicide application regime after several years of glyphosate application, and d) decline in agrobiodiversity (weed communities, herbivores, pollinators and beneficial species).

Our study reveals a lack of experimental data on potential agro-environmental effects. This suggests that the principle of a stepwise scale increase of release is inadequately applied to the GMHR sugar beet approval process. The adverse effects identified should prompt further research experiments to gain information for the ERA and/or specific monitoring activities at the respective identified spatial scale levels.
\end{abstract}

Keywords: Sugar beet, Genetically modified herbicide resistance, Risk assessment, Monitoring, Spatial scales

This review is licensed under a Creative Commons Attribution-Non-Commercial-NoDerivs 3.0 Germany License. http://creativecommons.org/licenses/by-nc-nd/3.0/de/ 


\section{Imprint / Terms of Use}

Living Reviews in Landscape Research is a peer reviewed open access journal published by the Leibniz Centre for Agricultural Landscape Research (ZALF), Eberswalder Straße 84, 15374 Müncheberg, Germany. ISSN 1863-7329.

This review is licensed under a Creative Commons Attribution-Non-Commercial-NoDerivs 3.0 Germany License: http://creativecommons.org/licenses/by-nc-nd/3.0/de/

Because a Living Reviews article can evolve over time, we recommend to cite the article as follows:

Frieder Graef, Gesine Schütte, Birgit Winkel, Hanka Teichmann and Martha Mertens, "Scale Implications for Environmental Risk Assessment and Monitoring of the Cultivation of Genetically Modified Herbicide-Resistant Sugar Beet: A Review", Living Rev. Landscape Res., 4, (2010), 3. [Online Article]: cited [<date $>$ ], http://www.livingreviews.org/lrlr-2010-3

The date given as $<$ date $>$ then uniquely identifies the version of the article you are referring to.

\section{Article Revisions}

Living Reviews supports two ways of keeping its articles up-to-date:

Fast-track revision A fast-track revision provides the author with the opportunity to add short notices of current research results, trends and developments, or important publications to the article. A fast-track revision is refereed by the responsible subject editor. If an article has undergone a fast-track revision, a summary of changes will be listed here.

Major update A major update will include substantial changes and additions and is subject to full external refereeing. It is published with a new publication number.

For detailed documentation of an article's evolution, please refer to the history document of the article's online version at http://www.livingreviews.org/lrlr-2010-3. 


\section{Contents}

1 Introduction $\quad 5$

2 Legal framework $\quad 8$

3 The sugar beet biology, geographical distribution and gene flow 10

4 HR technology with GM sugar beet and agricultural practice changes 12

5 Direct and indirect effects on the agro-environment $\quad 14$

6 Potential adverse agro-environmental effects across different spatial scale levels $\begin{array}{ll}\text { and implications for ERA and PMEM } & 18\end{array}$

7 A step-by-step scale approach for HR sugar beet? $\quad 23$

8 Conclusions 24

9 Acknowledgements $\quad 24$

10 Acronyms 24

$\begin{array}{lr}\text { References } & 25\end{array}$

\section{List of Tables}

1 Biological properties relevant to the ERA and PMEM across different spatial scale levels. . . . . . . . . . . . . . . . . . . . . . 11

2 Potential agro-enviromental effects across spatial scale levels linked to the HR technology and relevant to the ERA and PMEM. . . . . . . . . . . . . . . 15

3 Evidence of potential adverse agro-environmental effects and relevance for ERA and PMEM at different scale levels. . . . . . . . . . . . . . . . . . . . 20 



\section{Introduction}

Genetically modified herbicide-resistant (GMHR) sugar beet (Beta vulgaris L.) was deregulated in 2006 and introduced to the US and Canadian market in 2007. It was rapidly adopted by farmers and now accounts for nearly 95 percent of the acreage of all sugar beets produced in the US. The GMHR sugar beet is resistant to the herbicide active ingredient glyphosate. An application for cultivation of the variety H7-1 was made in Europe in 2008 and is currently in the approval process under Directive 2001/18/EC (European Commission, 2001). This regulatory framework specifies a systematic environmental risk assessment (ERA) and mandatory post-market environmental monitoring (PMEM) after approval. This is designed to handle uncertainties about potential adverse environmental effects still remaining after the ERA, which is primarily based on short-term and field-scale releases of the GM crops.

Various public and scientific concerns have been raised both in the US and in the EU about potential adverse agro-environmental effects of widespread GMHR sugar beet cultivation, leading to its provisional ban in some US states (Burkett, 2010). The concerns include cross-pollination with both conventional non-GM and organic Beta vulgaris varieties cultivated for sugar or for seed production (Lange et al., 1999; OECD, 2006), thereby reducing or even destroying their market value. Hybridisation with and gene flow to related wild species within the Beta section may occur (Bartsch et al., 2003; Sukopp et al., 2005), forming normally vigorous HR hybrids that may spread in the environment. The modified herbicide application regime with glyphosate includes multiple changes in cultivation practice (Graef, 2009) that may adversely impact the agro-environment and cause negative weed flora changes (Heard et al., 2003b,a; Roy et al., 2003), direct toxic environmental effects (Benachour and Séralini, 2009; Brausch and Smith, 2007; Relyea, 2005a,b,c), or the development of weed resistance through selection pressure (Heap, 2009; Zelaya et al., 2007). The concerns cover a wide range of environmental, agronomic, economic, and social aspects which are often partly interlinked, but our review focuses primarily on potential environmental and agronomic aspects of GMHR sugar beet cultivation.

Currently, the only GM crops approved for cultivation purposes in the EU are the Bt-Maize MON 810, which has been cultivated primarily in Spain, and the Amflora potato, which was approved in early March 2010. Despite their regulation under Directive 2001/18/EC (European Commission, 2001) and under the Supplementing Guidance Notes (European Commission, 2002), both the general approaches to ERA and the PMEM of GM crops are under continuing scientific debate. The quality and quantity of data provided on the ERA process presently does not satisfy scientific and technical standards (Dolezel et al., 2009). Moreover, the monitoring plans submitted and the monitoring reports presented by the applicants (BVL, 2007) still lack a profound science-based design. More general guidance on the ERA was developed by EFSA (2008). PMEM guidance was presented by ACRE (2004), more sharply delimiting the different monitoring intensity categories of general surveillance and case-specific monitoring.

Various additional scientific aspects have been developed and outlined in the last few years. These include a more targeted ERA involving well-defined hypotheses, precisely defined and prioritized hazards and quantifying elements of exposure (Andow and Hilbeck, 2004; Johnson et al., 2007; Wilkinson et al., 2003), the selection of test species for the risk assessment for non-target organisms (Hilbeck et al., 2008a), the selection of indicator organisms for the PMEM (Hilbeck et al., 2008b), systematic approaches for landscape-scale or ecoregion-based PMEM (Graef et al., 2005a,b), a science-based systematic step-by-step approach in PMEM (Züghart et al., 2008), the enhanced quality of statistics required for the ERA (Lövei and Arpaia, 2005; Perry et al., 2009), and a proposal for the definition of environmental damage (Bartz et al., 2009). Nonetheless, open questions and shortcomings in the present ERA and monitoring practice remain. Key issues to be further tackled are 
- improvements in guidance and standardization of risk assessment methodology, e.g., guidance on selecting representative locations for the assessment of agronomic and environmental behaviour of a particular GM crop, on the details of field trial designs, and on the risk assessment of long-term and cumulative effects (Dolezel et al., 2009),

- normative indications and thresholds for ecological hazards and damages associated with GM crops (Bartz et al., 2009; Breckling et al., 2009; Regal, 1994),

- the necessary field test and PMEM design required to yield scientifically sound data, (De Jong, 2010; Graef et al., 2005b; Lövei and Arpaia, 2005; Perry et al., 2009; Züghart et al., 2008)

- the ERA and monitoring data management and technical implementation using structured databases (Reuter et al., 2010a),

- the methodology of the ERA and monitoring of GM crops with multiple stacked transgenic events within one crop (De Schrijver et al., 2007),

- the methodology of data upscaling and interpretation as more field testing and monitoring data become available with more widely spread GM crop cultivation (ACRE, 2004; Breckling et al., 2009; Squire et al., 2009),

- the monitoring data coordination and harmonisation at national and/or EU levels (Finck et al., 2006; Graef et al., 2008),

- the applicability and use of existing national and/or EU environmental monitoring programmes and data infrastructure schemes for genetically modified organism (GMO) monitoring (Graef et al., 2005b; EU Monitoring Working Group, 2010).

The uncertainty connected to these key issues is also reflected in the often contradictory comments of EU member state experts during GM crop approval processes. Research is underway to tackle some of these shortcomings, for instance in national research programmes or as part of the Framework Programme on research by the European Commission.

So far, environmental risk-related data on GM plants is mainly concentrated on the lower levels of spatial extension such as molecular detection, laboratory trials, and short-term greenhouse or field studies to assess effects on the population level. Experiments on larger landscape scales are sparse, the most prominent being the Farm Scale Evaluations in the UK (Firbank et al., 2003). The usual ERA practice is to analyse and assess the greenhouse and field-scale results and extrapolate them to the European scale of (future) crop cultivation, potentially entailing large inference errors. Extrapolating ecological effects of GM crops from field scale to larger landscape scales, however, requires an up-scaling approach based on reliable data on various scales of GM exposition. This has been demonstrated in a special issue of the journal "Ecological Indicators" with GM oilseed rape (Brassica napus L.) (Breckling et al., 2009; Middelhoff et al., 2010; Reuter et al., 2010b). Many of those results are generally valid for other GM crops such as for GMHR sugar beet: it has certain biological features in common with oilseed rape, for instance wind-pollination, hybridisation with wild relatives, and persistent seeds in the soil.

It is important mentioning that not only GM crop but also the nonGM crop cultivation may entail various environmental effects that can occur on different spatial and temporal scales. Furthermore, the ecological importance of environmental effects is difficult to determine and may vary depending on the type of effect. Little focus has been placed on ERA and PMEM of sugar beet. This literature review is designed to identify likely adverse effects of GMHR sugar beet cultivation at the various spatio-temporal scales relevant for the ERA and the PMEM. The key question is whether experimental greenhouse- or field-scale-based data on specific potential adverse effects of

Living Reviews in Landscape Research

http://www. livingreviews.org/lrlr-2010-3 
GMHR sugar beet cultivation are scientifically-based and sufficient to be upscaled to larger areas such as landscapes. We thus identify the results and shortcomings of small- (field-) scale findings and indicate whether they enable inferring the outcomes at larger scales and on required PMEM.

In the context of this paper the term 'field organism' is defined as all organisms living in or visiting the field and its margins, such as plants, epigeic and endogeic invertebrates, birds, mammals and amphibians. The term 'herbicide resistance' is applied according to the WSSA (Weed Science Society of America) definition as the inherited ability of a plant to survive and reproduce following exposure to a dose of herbicide normally lethal to the wild type. In plants, resistance may be naturally occurring or induced by techniques such as genetic engineering or selection of variants produced by tissue culture or mutagenesis. The term 'agro-environment' is used here as the cultivated area along with neighbouring fields and biotopes. The different terms for scale levels used in this review are a) 'laboratory scale', b) 'greenhouse scale', c) 'field scale', which applies to pre-commercial experimental and large-scale field trials (European Commission, 2002) that are limited in number, their extension, and the duration of observations, and d) 'landscape scale'. The latter is the commercial GM plant cultivation scale and may range from smaller ecoregions, for instance at the 1:50,000 scale (Graef et al., 2005b), to larger climatic regions or ecoregions (Bailey, 2002; EFSA, 2008) or even (bio)geographical regions at the national or European scale (Eiden et al., 2000; Metzger et al., 2005). 


\section{Legal framework}

In accordance with the precautionary principle, the Directive 2001/18/EC (European Commission, 2001) regulates the releases, imports and cultivation of GM crops, applying a stepwise and systematic case-by-case assessment of the risks to human health and to the environment. Annex III B of the Directive 2001/18/EC specifies that the ERA shall encompass an evaluation of a) biological features of the parental plants such as reproduction, dissemination, survivability and geographical distribution, b) details of their genetic modification, c) harmful effects on human or animal health arising from the GM food/feed, d) interactions of the GM plant with the biotic and abiotic environment, and e) impacts of the specific cultivation, management and harvesting techniques. Important elements of this ERA are ecotoxicological tests at the research and development stage, investigating adverse effects of a GM plant in ecosystems that could be affected (Preamble 25 of Directive 2001/18/EC). It has to be demonstrated at each level that the risk for the environment is zero or negligible. In terms of duration and scales of release (Figure 1) the Directive distinguishes between a) experiments in the contained use system, b) deliberate release for experimental purposes, and c) release onto the market including cultivation.

Preamble 24 of the Directive 2001/18/EC recommends that "the introduction of GMOs into the environment should be carried out according to the 'step by step' principle." This means that the containment of GMOs is reduced and the scale of release increased gradually, step by step, but only if evaluation of the earlier steps in terms of protection of human health and the environment indicates that the next step can be taken. Risk-related research should thus be carried out initially in laboratories and greenhouses and then be followed by release-related research and monitoring. In premarket field trials, field plots are limited in time, number and space.

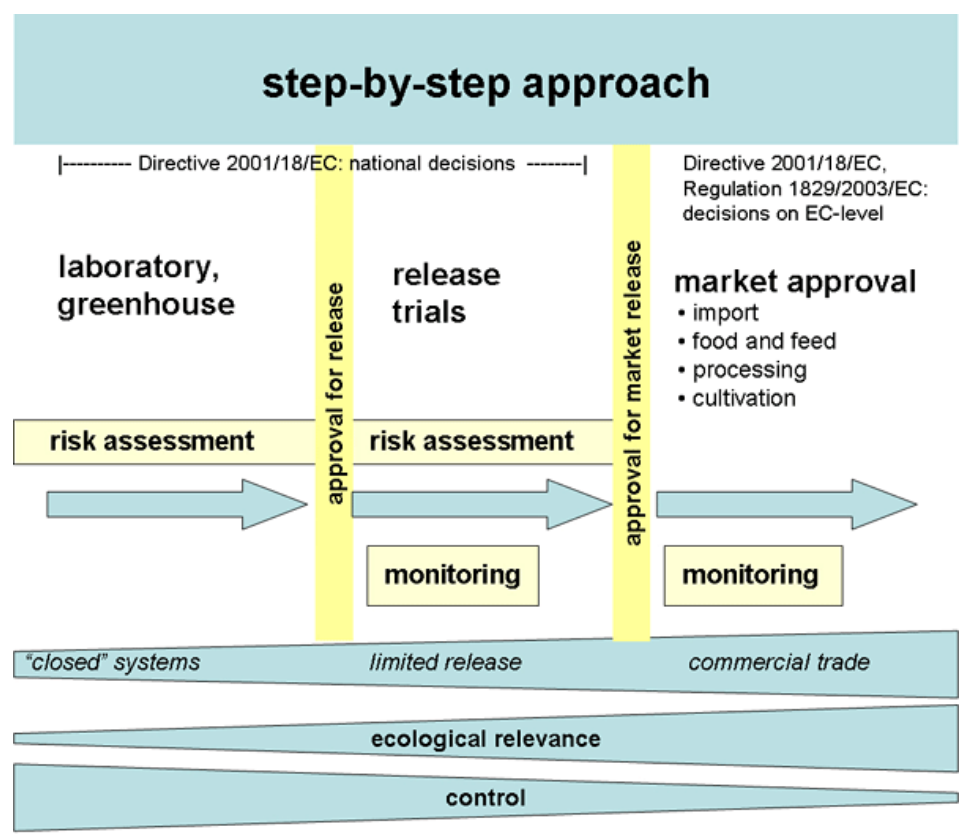

Figure 1: 'Step by step' principle for the release of GMOs (Züghart et al., 2008, modified).

In regulatory practice the step-by-step principle is often not followed. Especially the field testing of GMO in those ecosystems that could be affected in the case of commercial release is incomplete and, if done, the parameters assessed are mostly of agricultural and rarely of environmental value (Dolezel et al., 2009).

Living Reviews in Landscape Research

http://www. livingreviews.org/lrlr-2010-3 
For market-approved GMOs the Directive distinguishes (a) a case-specific monitoring (CSM) which focuses on direct and indirect, immediate and delayed potential effects on human health and the environment, identified in the preceding ERA process, and which is limited to a specified time period in which to obtain results and (b) a general surveillance (GS) that aims to identify and record indirect, delayed and/or cumulative adverse effects that have NOT been anticipated in a preceding ERA. In science, regulatory and monitoring practice, full non-anticipation for GS is not feasible. This is because, for any GS activity, there automatically is an effect hypothesis. In contrast to CSM, general surveillance should aim at identifying unforeseen and long-term effects and therefore be conducted over a longer time period and possibly wider area. The general definitions of CSM and GS leave some room for interpretation because cumulative effects, for example, may be either anticipated (then inducing CSM) or unforeseen (leading to GS). There are gradual differences in predictability among the effects. For instance, local effects on cropland can be more easily assessed than effects beyond cropland and on larger scales.

The monitoring results of marketed GMOs contribute to decisions regarding approval or additional precautions, and can enhance the certitude of prognosis for a future ERA. GM crop monitoring is intended to serve as an early warning system to react in case of reported adverse effects and then help in the decision-making process about countermeasures.

Once environmental changes are identified, it is essential to determine whether they are harmful or not. Adverse changes cannot always be attributed to a GMP because there are numerous influencing environmental and agricultural practice covariables (Graef, 2009; Hails, 2002; Stein and Ettema, 2003). If harmful, more in-depth studies are envisaged in order to detect causal relationships. In case of a relationship between a GMP and an adverse effect, measures to avoid or minimise effects must be taken. At the same time a new ERA is required. The subsequent results are the basis for decisions on extending GMP approvals, withdrawal of approval, modified risk management, and adaptations of the monitoring plan.

In the case of GMHR crops, there is an overlapping of competencies between the pesticide Directive 91/414/EEC (European Commission, 1991) and the Directive 2001/18/EC on the deliberate release of GMOs. Direct herbicide effects such as for glyphosate are regulated by Directive 91/414/EEC, but adverse effects due to a GMHR plant are not covered by the pesticide Directive. The European Commission therefore recommended that ERA and monitoring of herbicide effects of GMHR crop cultivation, as compared to conventional varieties, be done in the framework of Directive 2001/18/EC (DOC NR ENV/03/23). Some of the adverse effects discussed in the following will thus also fall into the remit of the pesticide Directive.

As outlined by Bartsch et al. (2009), the Directive 2004/35/EC on environmental liability specifically includes the handling and cultivation of GMO that potentially may cause environmental damage such as to protected species and natural habitats under Directive 92/43/EC (Natura 2000 habitats). Any damage that has significant adverse effects on reaching or maintaining the favourable conservation status of these legally defined protection goals must therefore be avoided. Some EU states and/or regions are therefore imposing cultivation bans for Bt-Maize and GM crop release restrictions for field tests within up to $1 \mathrm{~km}$ distance from Natura 2000 sites. BfN (2010) is hosting a mapping service in Germany to conform to these distance regulations. 


\section{The sugar beet biology, geographical distribution and gene flow}

The genus Beta is classified into four genetically differing sections, namely Beta, Corollinae, Nanae and Procumbentes (Lange et al., 1999; Frese, 1998). The species B. vulgaris ssp. vulgaris comprises the cultivated forms sugar beet (var. altissima), fodder beet (var. crassa), Swiss chard (var. vulgaris) and red beet (var. conditiva). The sugar beet has cultivar, wild and weed forms. Wild beet species are quite common among the Beta section, comprising the subspecies Vulgaris, Maritima, Adanensis and the closely related species B. patula and B. macrocarpa. They occur along the coasts of northern and western Europe and in the Mediterranean area including north-west Africa and the Canary Islands, the Balkans, the Caucasus and from Asia Minor to Bangladesh (Table 1) (Frese, 1998).

Sugar beets are most often self-incompatible and usually wind-pollinated, although insect pollination is also possible (Bartsch et al., 1999). Sugar beet hybridises easily with cultivated and wild forms of Beta vulgaris. It has normally vigorous and fertile progeny without incompatibilities with members within the Beta section (OECD, 2006). Natural interspecific hybridisation between the species of section Beta is also possible, but is very unlikely with species of the other three Beta sections. If hybridisation between B. vulgaris and other sections occurs either naturally or through artificial techniques, the resulting progeny is not viable and does not reach the generative phase (Van Geyt et al., 1990). Thus, a gene transfer from cultivated beets to wild beets is likely only for the Beta section.

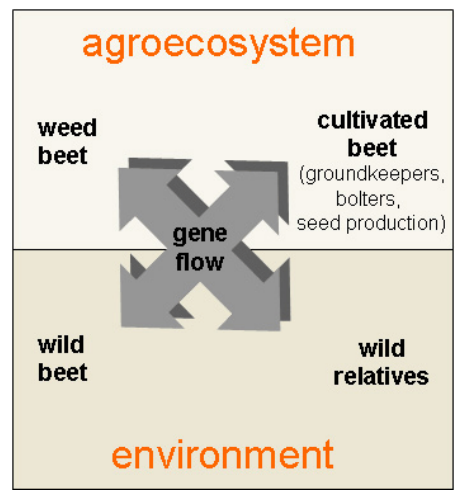

Figure 2: Intra- and interspecific gene flow of cultivated, weedy, wild sugar beet and related wild species within and between agricultural fields and the environment (Bartsch et al., 2003, modified).

Sugar beets are biennial plants forming a beet in their first season. If the beets are not harvested, flowering shoots appear in the second year after vernalisation. However, the formation of flowering shoots and completion of the whole life cycle in the first year is possible (bolters) (probability $<0.05 \%$ ) due to the genetic constitution of the plants and/or certain weather conditions such as drought or frost (Keller et al., 1999; Geisler, 1980). In practice, bolters are usually removed or destroyed before flowering. Seeds from bolters that have not been removed before seed maturity fall off and pass into the soil seed bank. From these seeds, weed beets can emerge within and between rows in the crop stand in the following years (May, 2009). The seeds can have a life span of over 10 years, but are depleted with time or may germinate under favourable conditions. Small beets or beet sections left in the field after harvesting can regenerate (groundkeepers) (Elliott and Weston, 1993) depending on the part of the plant, size, depth of placement, survival ratio, and management of the following crop (Buddemeyer and Petersen, 2002). Bolters and volunteers in some years with special conditions can become overwhelming, hindering their management or eradication by farmers. Hence, gene flow via seed, pollen or clonal plant parts within and between agroecosystem and the environment is possible in various ways and directions (Figure 2).

Living Reviews in Landscape Research

http://www. livingreviews.org/lrlr-2010-3 
Table 1: Biological properties relevant to the ERA and PMEM across different spatial scale levels.

\begin{tabular}{|c|c|c|c|c|c|}
\hline \multirow{2}{*}{$\begin{array}{l}\text { Biological properties } \\
\text { of Beta vulgaris L. }\end{array}$} & \multirow{2}{*}{$\begin{array}{l}\text { Chain of potential agro- } \\
\text { environmental effects }\end{array}$} & \multicolumn{3}{|c|}{ References $^{1}$} & \multirow{2}{*}{$\begin{array}{l}\text { Evi- } \\
\text { dence }^{2}\end{array}$} \\
\hline & & $\begin{array}{l}\text { laboratory } \\
\text { or green- } \\
\text { house } \\
\text { experi- } \\
\text { ments }\end{array}$ & $\begin{array}{l}\text { field tri- } \\
\text { als or } \\
\text { observa- } \\
\text { tions }\end{array}$ & $\begin{array}{l}\text { landscape- } \\
\text { scale } \\
\text { experi- } \\
\text { ments or } \\
\text { observa- } \\
\text { tions }\end{array}$ & \\
\hline $\begin{array}{l}\text { widespread geographical } \\
\text { distribution of Beta } \\
\text { vulgaris L., wild beets } \\
\text { and bastards in some } \\
\text { EU regions }\end{array}$ & $\begin{array}{l}\rightarrow \text { potential of HR sugar beet } \\
\text { to hybridise with neighbouring } \\
\text { cultivated, feral and weed beets }\end{array}$ & 1 & 1,8 & $1,2,3$ & high \\
\hline $\begin{array}{l}\text { widespread geograph- } \\
\text { ical distribution of re- } \\
\text { lated wild species of the } \\
\text { genus Beta L. }\end{array}$ & $\begin{array}{l}\rightarrow \text { potential of HR sugar beet to } \\
\text { hybridise with wild relatives }\end{array}$ & & & $3,4,13$ & high \\
\hline formation of bolters & $\begin{array}{l}\rightarrow \text { in case of flowering: hybridisa- } \\
\text { tion of HR sugar beet with neigh- } \\
\text { bouring cultivated, feral and weed } \\
\text { beets, and with related species } \rightarrow \\
\text { seed production }\end{array}$ & $\begin{array}{l}2,5,6,10 \\
11\end{array}$ & $\begin{array}{l}2,5,6,7 \\
8,10,11 \\
14,15 \\
16,31,32\end{array}$ & $\begin{array}{l}2,7,8 \\
9,10,11 \\
12,20,27\end{array}$ & high \\
\hline $\begin{array}{l}\text { regeneration of vege- } \\
\text { tative plant residues } \\
\text { for the next season } \\
\text { (groundkeepers) }\end{array}$ & $\begin{array}{l}\rightarrow \text { in case of flowering: hybridisa- } \\
\text { tion of HR sugar beet with neigh- } \\
\text { bouring cultivated, weed and wild } \\
\text { beets, and with related species } \rightarrow \\
\text { seed production }\end{array}$ & $2,5,6,18$ & $\begin{array}{l}2,5,6,7 \\
8,14,17 \\
18,25 \\
26,31,32\end{array}$ & $\begin{array}{l}7,8,9 \\
12,20 \\
27\end{array}$ & high \\
\hline \multirow[t]{3}{*}{$\begin{array}{l}\text { stable weed beet popu- } \\
\text { lations }\end{array}$} & $\begin{array}{l}\rightarrow \text { increase of HR seed bank, } \rightarrow \\
\text { hybridisation with neighbouring } \\
\text { cultivated and/or wild relatives } \\
\rightarrow \text { in case of a selective advantage } \\
\text { and/or genetic drift: HR sugar } \\
\text { beet and related species may per- } \\
\text { sist and become invasive }\end{array}$ & & $\begin{array}{l}12,14 \\
16,19 \\
25,26 \\
31,32\end{array}$ & $19,20,30$ & high \\
\hline & $\begin{array}{l}\rightarrow \text { unpredictable combinatory } \\
\text { effects with cultivated and/or } \\
\text { wild relatives }\end{array}$ & & 23 & & low \\
\hline & $\begin{array}{l}\rightarrow \text { adverse effects on neighbouring } \\
\text { habitats such as ecosystem food } \\
\text { chains; impacts on biodiversity }\end{array}$ & & 24 & 28 & low \\
\hline horizontal gene transfer & $\begin{array}{l}\rightarrow \text { transgenes may be transferred } \\
\text { to other species such as bacteria }\end{array}$ & $21,22,29$ & & & medium \\
\hline
\end{tabular}

${ }^{1}$ References legend (E: Expert opinions; M: Models; R: Review; O: Original data): 1 (Drießen et al., 2001 / O, R); 2 (OECD, 2006 / R); 3 (Frese, 1998 / R); 4 (Frese et al., 2001 / O, R); 5 (Van Geyt et al., 1990 / R); 6 (Bartsch and Schmidt, 1997 / O); 7 (Bartsch et al., 1999 / O); 8 (Bartsch et al., 2003 / O, R); 9 (Sukopp et al., 2005 / O, R); 10 (Keller et al., 1999 / R); 11 (Geisler, 1980 / R); 12 (Beckie, 2006 / E); 13 (De Bock, 1986 / R); 14 (May, 2009 / E); 15 (Lehnert, 2007 / E); 16 (Viard et al., 2002 / O); 17 (Elliott and Weston, 1993 / E); 18 (Buddemeyer and Petersen, 2002 / O); 19 (Soukup et al., 2002); 20 (Desplanque et al., 2002 / O, E); 21 (Heinemann and Traavik, 2004 / O); 22 (Nielsen and Townsend, 2004 / O); 23 (Pessel et al., 2001); 24 (Watkinson et al., 2000 / M, E); 25 (Märländer et al., 2010 / R); 26 (Viard et al., 2002); 27 (Boudry et al., 1993); 28 (Züghart and Breckling, 2003 / R); 29 (Rensing et al., 2002 / O); 30 (Cerdeira and Duke, 2006 / R); 31 (Arnaud et al., 2003 / O); 32 (Arnaud et al., 2009 / O)

${ }^{2}$ Evidence among the references based on the data quality aspects a) how closely the measured or observed features, effects and indicators resemble the actual features, effects and indicators about which information is desired; b) quality, mode and accuracy of the methodological design and the degree to which empirical or expert observations have been used to produce the data; c) statistical design, number of replications, spatio-temporal representativeness (Graef, 2009) 


\section{HR technology with GM sugar beet and agricultural prac- tice changes}

Experience with GMHR sugar beet cultivation is limited to the US and Canada, where this GM plant has been grown since 2007. Nonetheless, some conclusions can also be drawn from the long-term cultivation of GMHR oilseed rape (Graef, 2009). The introduction of GMHR sugar beet cultivation and its HR technology in Europe will alter existing cropping systems and lead to various practice changes (Benbrook, 2009; Champion et al., 2003) that may entail agro-environmental effects (Table 2). Locally, GMHR sugar beet cultivation may be expanded to areas that, due to weed pressure, were less suitable for cultivation before.

Herbicide application pattern: In HR sugar beet cultivation, only the broad-spectrum herbicide glyphosate is applied, usually first at the post-emergence stage and second until 60$70 \%$ canopy closure. This makes timing more flexible and simplifies weed control (Champion et al., 2003). In conventional agriculture, usually three to four (up to six) herbicide applications are done, with glyphosate often applied at the pre-seeding or pre-emergent stage to clear fields and postharvest for volunteer control (Märländer, 2005; Schütte and Mertens, 2010), while other herbicides are applied during crop development. With HR sugar beet cultivation, the aim is also to reduce the active ingredient (ai) amount and the number of herbicides. For the case of GMHR oilseed rape in the US and Canada, this holds true only for the first years of cultivation (Champion et al., 2003; Benbrook, 2009).

Similarities between sugar beet and oilseed rape rotations (break crops in cereal-dominated rotations typically grown one year in every three, four or five years) and biology (hybridisability, volunteer occurrence, wild relatives) allow changes in agricultural practice to be postulated after years of continued HR technology: a) weeds may become herbicide-tolerant through selection pressure and adaptation, especially if different HR crops resistant to glyphosate are cultivated in the same rotation (Beckie et al., 2006; Owen and Zelaya, 2005), b) the composition of weed communities and their seed bank will change (Heard et al., 2003a; Owen and Zelaya, 2005), and consequently, c) ai rates, application frequencies, and numbers of ai may increase again, particularly in low-disturbance seeding systems (Senior and Dale, 2002).

Gene flow and volunteers: Not eradicating sugar beet bolters and groundkeepers before flowering may lead to gene flow of the HR trait and to seed dispersal, although at rates far below those encountered with oilseed rape, for example, which regularly flowers and produces seeds. HR volunteers may occur in subsequent rotations when seeds of bolters and groundkeepers fall to the ground (Bartsch et al., 2003; Keller et al., 1999). HR weedy relatives or interspecific hybrids (Arnaud et al., 2003; Frese et al., 2001) may evolve due to pollen-mediated gene flow from HR bolters and HR groundkeepers. HR volunteers may also evolve in non-HR sugar beet fields due to pollen-mediated gene flow from flowering HR bolters and HR groundkeepers to neighbouring sugar beet fields, and also due to neighbouring volunteers from sugar beet seed banks (Desplanque et al., 2002; Viard et al., 2002). When neighbouring sugar beets with other HR traits are cultivated, multiple HR may develop in weed beet; selective advantage then maintains this, as evident in North America with GMHR oilseed rape (Beckie et al., 2006; Orson, 2002).

In sugar beet seed production areas, seed purity standards include minimum distances between fields to avoid cross-pollination (Märländer et al., 2010). Nonetheless, outcrossing into wild relatives may occur, also because the amount of GMHR sugar beet pollen is likely to be higher than that of neighbouring wild relatives.

Tillage and rotation system: GMHR sugar beet facilitates the use of enhanced crop cover and no-tillage or reduced-tillage. This, in turn, minimizes weed pressure and soil compaction, prevents soil erosion and promotes soil bioactivity (Agronomy Guide, 2010; Thorbek and Bilde, 2004). If HR sugar beet weeds and volunteers in the follow crops develop as a result of flowering bolters and/or groundkeepers, the necessary control may trigger more intensive tillage and/or may

Living Reviews in Landscape Research

http://www. livingreviews.org/lrlr-2010-3 
require wider rotations or crops with other HR traits. Since seeds may persist for years in the soil, returning to a conventional sugar beet in the crop rotation may become difficult due to HR volunteers and their admixture in the harvest.

Coexistence: Avoiding GM material presence in non-GM crop production practice may require changes in GMHR sugar beet cultivation (European Commission, 2003). Normal farming practice involves preventing flowering and thus reducing vertical gene flow to neighbouring fields. Depending on various factors, flowering bolters and/or groundkeepers can sometimes be encountered; they act as pollen donators or acceptors, producing HR seeds. Despite the potentially low rate of gene flow to avoid contamination of non-GMHR sugar beet fields and potential HR seed production, this calls for coexistence measures such as isolating fields of GM sugar beet, introducing isolation distances, and sowing and harvesting at a modified time schedule, preferably using other varieties (Schiemann, 2003). In sugar beet seed production areas, flowering is necessary; to guarantee seed purity standards, seed companies have introduced various temporal and spatial isolation measures. 


\section{Direct and indirect effects on the agro-environment}

The biological features, combined with the HR technology, as shown above, may entail direct, indirect, immediate, delayed and/or cumulative agro-environmental effects (Table 1 and 2).

Effects on the agro-environment may be induced by single or several different mechanisms; these may work singly or cumulatively (Graef, 2009). The agro-environmental effects may be detected at a single scale or at multiple levels.

Section 6 discusses whether the effects are considered to be adverse, positive, not relevant or relevant for monitoring, whether they require further studies for the ERA or raise the concern of an environmental risk leading to deny approval, or whether they may constitute an environmental damage (Bartz et al., 2009) that merits withdrawal of approval.

Effects directly or indirectly linked to sugar beet biology: Bolting, formation of groundkeepers, along with the high rate and distance of pollen spread and cross-pollination (Drießen et al., 2001; OECD, 2006) may trigger HR gene flow to neighbouring non-GM sugar beet, weed beets, wild beets and related wild species. The preconditions are spatial concurrence (Frese, 1998) and inefficient prevention of flowering by agricultural practice.

The potential increase of HR sugar beet in the seed banks, which may incorporate viable HR seeds over 10 years, may lead to persisting and invasive HR weed beets, wild beets and related wild species in fields and natural habitats. The preconditions: a selection advantage due to repeated glyphosate application, enhanced fitness parameters and genetic drift. Wilkinson et al. (2000) and Snow (2003) observed this for HR oilseed rape. Cultivated beet genes can persist in wild beet (Bartsch et al., 1999; Sukopp et al., 2005). If HR weed beets, wild beets and related wild species become invasive, this may variously impact habitats, food chains and biodiversity (Watkinson et al., 2000; Züghart and Breckling, 2003).

A horizontal gene transfer of HR from plant residues to soil microorganisms is rare but possible, irrespective of the HR trait (Heinemann and Traavik, 2004; Nielsen and Townsend, 2004), but its environmental implications are hard to determine. Another general ecological concern is the potential for a) adverse combinatory effects when GMHR sugar beet hybridises with weed beets, wild beets and related wild species that potentially affect the hybrid's biology and/or herbivores and b) pleiotropic and epigenetic genome effects of the GM crop caused by the genetic modification procedure, as shown for instance with GM wheat (Zeller et al., 2010). These unintended and unanticipated effects, for instance on non-target organisms (NTOs), must be considered, especially when performing the ERA (GMO Panel, 2010).

Effects directly or indirectly linked to the HR technology: More efficient weed suppression leads to less biomass, food and flowers for field organisms after spraying. This, in turn, entails lower abundances of various herbivores, pollinators and beneficial species (pest antagonists) (Bohan et al., 2005; Heard et al., 2003b), and may decrease agrobiodiversity (Watkinson et al., 2000). A shift in weedy species (Heard et al., 2003b,a) and an increase of perennial weeds due to minimum-till practice is likely (Frick and Thomas, 1992). Extending the HR technology may have various potential effects on field organisms and soil bio-geochemical cycles on the larger landscape scale (Benton et al., 2002; Cerdeira and Duke, 2006). Another ecological concern is possible adverse indirect effects on migratory and mobile species, leaf litter quality, crop competitiveness, and insect resistance (Squire et al., 2003).

Applying glyphosate formulations compared to other herbicides has adverse effects on fields and neighbouring habitats. These include increased mortality of amphibians (Relyea, 2005a,b,c) and mammals (Richard et al., 2005; Benachour and Séralini, 2009) and, in combination with simultaneous exposure to parasites, reduced survival of freshwater fish (Kelly et al., 2010). Adverse direct or indirect glyphosate effects were also reported for micronutrient uptake (Tesfamariam et al., 2009), soil microflora and plant disease severity (Fernandez et al., 2009; Heuer et al., 2002; Johal and Huber, 2009; Kremer and Means, 2009). This can hamper soil functions or bio-geochemical

Living Reviews in Landscape Research

http://www. livingreviews.org/lrlr-2010-3 
cycles (Züghart and Breckling, 2003). Glyphosate formulations containing surfactants such as POEA (polyethoxylated tallow amine) are more toxic than the ai glyphosate alone (Benachour and Séralini, 2009), in particular for aquatic organisms (Brausch and Smith, 2007). Some studies also indicate less herbicide toxicity and persistency than other herbicides (Agronomy Guide, 2010; Cerdeira and Duke, 2006; Squire et al., 2003).

Until post-emergent spraying, more biomass is available for feeding organisms (Werner et al., 2000; Strandberg et al., 2005). After spraying, however, biomass drops compared to conventional spraying. Furthermore, spraying is usually done before weed seed development (Dewar et al., 2000), reducing the weed seed bank in the long term. Early band applications combined with late overall treatments may enhance biomass availability during the growing period (May et al., 2005). Nonetheless, seed development and abundance in arable flora are also reduced in the long run. Post-emergent spraying may increase herbicide drift into the agro-environment, for example due to increased spraying height (Johnson, 2001). Post-emergent spraying also often entails a change in spray schedules of insecticides and fungicides, with potential implications for microbial and faunal activity (Champion et al., 2003; Thorbek and Bilde, 2004).

To control possible HR sugar beet volunteers in follow crops, modified crop rotations may be necessary. This may require farmers to change the tillage system (Schütte et al., 2004), affecting field organisms and soil bio-geochemical cycles (McLaughlin and Mineau, 1995; Orson, 2002). It may also require more ai, different types of herbicides or higher spraying frequency to control HR in weeds (Van Acker et al., 2003). Again, this can impact agrobiodiversity. Coexistence measures to reduce gene flow may change agricultural practice and entail various environmentally relevant effects.

Table 2: Potential agro-enviromental effects across spatial scale levels linked to the HR technology and relevant to the ERA and PMEM (Graef, 2009, modified).

\begin{tabular}{|c|c|c|c|c|c|}
\hline \multirow[t]{2}{*}{ Practice changes } & \multirow{2}{*}{$\begin{array}{l}\text { Chain of potential agro- } \\
\text { environmental effects }\end{array}$} & \multicolumn{3}{|c|}{ References $^{1}$} & \multirow{2}{*}{$\begin{array}{l}\text { Evi- } \\
\text { dence }^{2}\end{array}$} \\
\hline & & $\begin{array}{l}\text { laboratory } \\
\text { or green- } \\
\text { house } \\
\text { experi- } \\
\text { ments }\end{array}$ & $\begin{array}{l}\text { field tri- } \\
\text { als or } \\
\text { observa- } \\
\text { tions }\end{array}$ & $\begin{array}{l}\text { landscape- } \\
\text { scale } \\
\text { experi- } \\
\text { ments or } \\
\text { observa- } \\
\text { tions }\end{array}$ & \\
\hline \multirow[t]{4}{*}{$\begin{array}{l}\text { introduction of HR } \\
\text { technology }\end{array}$} & $\begin{array}{l}\text { increased weed suppression } \rightarrow \\
\text { less biomass, food, flowers and } \\
\text { habitats for field organisms af- } \\
\text { ter spraying } \rightarrow \text { lower abundance } \\
\text { of various herbivores, pollina- } \\
\text { tors and beneficial species (pest } \\
\text { antagonists) } \rightarrow \text { decrease in agro- } \\
\text { biodiversity }\end{array}$ & & 20,25 & $\begin{array}{l}3,6,7, \\
9,28,33, \\
36,37,38\end{array}$ & high \\
\hline & $\begin{array}{l}\text { development of herbicide toler- } \\
\text { ance in weeds }\end{array}$ & & & $\begin{array}{l}3,4,9 \\
16,35,44\end{array}$ & high \\
\hline & reduced crop rotation options & & & 3,9 & medium \\
\hline & $\begin{array}{l}\text { decrease and/or shift of weedy } \\
\text { species and weed seedbank }\end{array}$ & & & $\begin{array}{l}4,16,28, \\
33,35 \\
36,37 \\
38,44\end{array}$ & high \\
\hline
\end{tabular}

Continued on next page... 
Table 2 - Continued

\begin{tabular}{|c|c|c|c|c|c|}
\hline \multirow[t]{2}{*}{ Practice changes } & \multirow{2}{*}{$\begin{array}{l}\text { Chain of potential agro- } \\
\text { environmental effects }\end{array}$} & \multicolumn{3}{|c|}{ References $^{1}$} & \multirow{2}{*}{$\begin{array}{l}\text { Evi- } \\
\text { dence }^{2}\end{array}$} \\
\hline & & $\begin{array}{l}\text { laboratory } \\
\text { or green- } \\
\text { house } \\
\text { experi- } \\
\text { ments }\end{array}$ & $\begin{array}{l}\text { field tri- } \\
\text { als or } \\
\text { observa- } \\
\text { tions }\end{array}$ & $\begin{array}{l}\text { landscape- } \\
\text { scale } \\
\text { experi- } \\
\text { ments or } \\
\text { observa- } \\
\text { tions }\end{array}$ & \\
\hline & $\begin{array}{l}\text { little or no evidence: impact on } \\
\text { migratory and mobile species, } \\
\text { changed quality of plant parts, } \\
\text { changed crop competitive- } \\
\text { ness, changed insect resistance, } \\
\text { pleiotropic and epigenetic genome } \\
\text { effects, impact on soil functions }\end{array}$ & 46 & 20,23 & $\begin{array}{l}4,21,22, \\
36\end{array}$ & low \\
\hline $\begin{array}{l}\rightarrow \text { reduced herbicide } \\
\text { ai amount, reduced } \\
\text { no. of spray rounds, } \\
\text { use of glyphosate only }\end{array}$ & $\begin{array}{l}\text { less negative impacts on field } \\
\text { organisms and/or soil compaction }\end{array}$ & & $1,23,25$ & $\begin{array}{l}2,3,12, \\
13\end{array}$ & high \\
\hline $\begin{array}{l}\rightarrow \text { higher herbicide } \\
\& \text { insecticide applica- } \\
\text { tions in formerly not } \\
\text { cultivated areas }\end{array}$ & $\begin{array}{l}\text { various adverse effects on field } \\
\text { and aquatic organisms and/or soil } \\
\text { bio-geochemical cycles }\end{array}$ & 43 & & $\begin{array}{l}3,22,23 \\
29,31\end{array}$ & high \\
\hline $\begin{array}{l}\rightarrow \text { glyphosate use } \\
\text { instead of other more } \\
\text { persistent or toxic } \\
\text { herbicides }\end{array}$ & $\begin{array}{l}\text { less residual activity to fol- } \\
\text { lowcrops, less adverse effects on } \\
\text { field organisms }\end{array}$ & & 46 & $2,4,8$ & medium \\
\hline \multirow[t]{2}{*}{$\begin{array}{l}\rightarrow \text { glyphosate use } \\
\text { instead of other less } \\
\text { toxic herbicides }\end{array}$} & $\begin{array}{l}\text { adverse effects on field organisms } \\
\text { and/or aquatic communities in } \\
\text { cropped fields and neighbouring } \\
\text { habitats, higher glyphosate con- } \\
\text { centrations in surface and ground } \\
\text { waters }\end{array}$ & 26,40 & & $\begin{array}{l}4,22,36, \\
41\end{array}$ & high \\
\hline & $\begin{array}{l}\text { adverse effects on fungal com- } \\
\text { munities, diseases and nutrient } \\
\text { availability }\end{array}$ & 10 & $\begin{array}{l}10,11 \\
15,39\end{array}$ & 10,45 & high \\
\hline \multirow[t]{3}{*}{$\begin{array}{l}\rightarrow \text { post-emergent } \\
\text { spraying }\end{array}$} & $\begin{array}{l}\text { more biomass for feeding organ- } \\
\text { isms until spraying }\end{array}$ & & 25 & $\begin{array}{l}5,9,28 \\
33,36\end{array}$ & high \\
\hline & $\begin{array}{l}\text { less erosion due to more weed } \\
\text { biomass and residues }\end{array}$ & & & 4,8 & medium \\
\hline & $\begin{array}{l}\text { increased drift and pollution due } \\
\text { to higher late-season wind speeds } \\
\text { and/or increased spraying height }\end{array}$ & & 6,27 & 22 & medium \\
\hline $\begin{array}{l}\rightarrow \text { change in spray } \\
\text { schedules of insecti- } \\
\text { cides and fungicides } \\
\text { due to modified her- } \\
\text { bicide spraying }\end{array}$ & $\begin{array}{l}\text { positive or negative implications } \\
\text { for microbial and/or fauna activi- } \\
\text { ties }\end{array}$ & & & $\begin{array}{l}9,13,22, \\
37\end{array}$ & medium \\
\hline $\begin{array}{l}\rightarrow \text { minimum till asso- } \\
\text { ciated with HR sugar } \\
\text { beet cultivation }\end{array}$ & $\begin{array}{l}\text { increased competitiveness of } \\
\text { perennial weeds }\end{array}$ & & & 14,32 & high \\
\hline
\end{tabular}

Continued on next page... 
Table 2 - Continued

\begin{tabular}{|c|c|c|c|c|c|}
\hline \multirow[t]{3}{*}{ Practice changes } & \multirow{2}{*}{$\begin{array}{l}\text { Chain of potential agro- } \\
\text { environmental effects }\end{array}$} & \multicolumn{3}{|c|}{ References $^{1}$} & \multirow{2}{*}{$\begin{array}{l}\text { Evi- } \\
\text { dence }^{2}\end{array}$} \\
\hline & & $\begin{array}{l}\text { laboratory } \\
\text { or green- } \\
\text { house } \\
\text { experi- } \\
\text { ments }\end{array}$ & $\begin{array}{l}\text { field tri- } \\
\text { als or } \\
\text { observa- } \\
\text { tions }\end{array}$ & $\begin{array}{l}\text { landscape- } \\
\text { scale } \\
\text { experi- } \\
\text { ments or } \\
\text { observa- } \\
\text { tions }\end{array}$ & \\
\hline & $\begin{array}{l}\text { less soil compaction, higher soil } \\
\text { biodiversity }\end{array}$ & & 24,34 & $4,8,9$ & high \\
\hline \multirow[t]{2}{*}{$\begin{array}{l}\text { control of HR sugar } \\
\text { beet volunteers in } \\
\text { followcrops }\end{array}$} & $\begin{array}{l}\text { reduced crop rotation options } \\
\text { (e.g., wider rotations or crops } \\
\text { with other HR traits) } \rightarrow \text { various } \\
\text { positive or negative implications } \\
\text { for field organisms and soil bio- } \\
\text { geochemical cycles }\end{array}$ & & & 3,32 & low \\
\hline & $\begin{array}{l}\text { changes in tillage system } \rightarrow \text { pos- } \\
\text { itive or negative implications for } \\
\text { soil degradation and erosion }\end{array}$ & & & $3,17,32$ & medium \\
\hline \multirow[t]{2}{*}{$\begin{array}{l}\text { control of increased } \\
\mathrm{HR} \text { in weeds }\end{array}$} & $\begin{array}{l}\text { increased ai amount, different } \\
\text { types of herbicides, higher spray- } \\
\text { ing frequency }\end{array}$ & & & $\begin{array}{l}3,12,18 \\
22,42\end{array}$ & high \\
\hline & $\begin{array}{l}\rightarrow \text { various adverse effects on } \\
\text { field organisms and/or soil bio- } \\
\text { geochemical cycles }\end{array}$ & & 25 & $\begin{array}{l}3,17,29, \\
32\end{array}$ & high \\
\hline $\begin{array}{l}\text { in case of increased } \\
\text { yield potential } \rightarrow \\
\text { increased fertiliser use }\end{array}$ & increased nutrient leaching & & 8 & 30 & medium \\
\hline \multirow[t]{2}{*}{$\begin{array}{l}\text { coexistence measures } \\
\text { to reduce vertical } \\
\text { gene flow }\end{array}$} & $\begin{array}{l}\text { reduced crop rotation options, } \\
\text { isolating fields of GMHR sugar } \\
\text { beet }\end{array}$ & & & 13,19 & medium \\
\hline & $\begin{array}{l}\rightarrow \text { various positive or negative } \\
\text { implications for field organisms } \\
\text { and/or soil bio-geochemical cycles }\end{array}$ & & & $22,26,32$ & medium \\
\hline
\end{tabular}

${ }^{1}$ References legend (E: Expert opinions; M: Models; R: Review; O: Original data): 1 (Champion and May, 2004 O); 2 (Kleter et al., 2007 R); 3 (Schütte et al., 2004 E, R); 4 (Cerdeira and Duke, 2006 R); 5 (Bohan et al., 2005 O); 6 (Owen, 1999 E); 7 (Krebs et al., 1999 E, R); 8 (Agronomy Guide, 2010 E, O); 9 (Werner et al., 2000 E, M, R); 10 (Johal and Huber, 2009 R); 11 (Fernandez et al., 2009 O); 12 (Benbrook, 2009 R, O); 13 (Champion et al., 2003 O); 14 (Frick and Thomas, 1992 O); 15 (Tesfamariam et al., 2009 O); 16 (Beckie et al., 2006 R, O); 17 (Van Acker et al., 2003 E, R); 18 (Légère, 2005 E, R); 19 (Schiemann, 2003 E); 20 (Firbank and Forcella, 2000 E, R); 21 (Regal, 1994 E, R); 22 (Züghart and Breckling, 2003 R); 23 (Watkinson et al., 2000 M, E); 24 (Jordan et al., 2004 O); 25 (Strandberg et al., 2005 O); 26 (Relyea, 2005a,b,c O); 27 (Johnson, 2001 E, O); 28 (Heard et al., 2003b O); 29 (Robinson and Sutherland, 2002 R, O); 30 (Pacini et al., 2003 O); 31 (Benton et al., 2002 R, O); 32 (McLaughlin and Mineau, 1995); 33 (Heard et al., 2003a O); 34 (Thorbek and Bilde, 2004 O); 35 (Owen and Zelaya, 2005 / O); 36 (Squire et al., 2003 O); 37 (Hole et al., 2005 R); 38 (Firbank et al., 2006 O); 39 (Larson et al., 2006 O); 40 (Benachour and Séralini, 2009 O); 41 (Popp et al., 2008 O); 42 (Sanyal et al., 2008 E,O); 43 (Kelly et al., 2010 O); 44 (Johnson et al., 2009 R); 45 (Kremer and Means, 2009 O); 46 (Zobiole et al., 2010 / O)

${ }^{2}$ Evidence of effects among the references based on the data quality aspects a) how closely the measured or observed effects and indicators resemble the actual effects and indicators about which information is desired; b) quality, mode and accuracy of the methodological design and the degree to which empirical or expert observations have been used to produce the data; c) statistical design, number of replications, spatio-temporal representativeness (Graef, 2009) 


\section{Potential adverse agro-environmental effects across differ- ent spatial scale levels and implications for ERA and PMEM}

As shown above, the combination of biological properties and the modified HR technology may entail various positive, neutral or adverse agro-environmental effects. These can be demonstrated to varying degrees by scientific observations and/or experiments, each of which were made on various scales of precision, space and time (Figure 3). Compiling this information helps in the overall assessment of the evidence for potential agro-environmental effects (Table 1 and 2). This information is collected and investigated for the ERA of the HR sugar beet, and conclusions can be drawn for the PMEM. If information on specific aspects of the HR sugar beet is considered insufficient, further observations and experiments may be required.

An important aspect of the ERA procedure is to evaluate effects, i.e., are they adverse and do they constitute environmental damage. This is a function of hazard and likelihood of occurrence. The mere occurrence of a GM crop, for instance in arable non-GM fields or other biotopes, is not considered damage, but rather as an indicator for potential damage. According to Bartz et al. (2009), an adverse effect can be defined as a reduction in valued attributes of one or more conservation resources. Moreover, environmental damage can be defined as a significant adverse effect on a biotic or abiotic conservation resource that has an impact a) on the environmental value of the conservation resource in whole or part, b) on the conservation resource as an ecosystem component, or c) on the sustainable use of the conservation resource or the ecosystem. This implies that components (composition, structure, functions) and scale levels (gene, species, ecosystem, landscape) of a conservation resource are considered in their entirety (Bartz et al., 2009, Figure 3). Once an adverse effect is detected and sufficiently evidenced, its significance, which ultimately is an operational threshold value, must be assessed on a normative basis. It may then be considered as significant or not significant. If the significance is low or cannot yet be assessed, it can be allocated either to general surveillance (GS) or to a case-specific monitoring (CSM) (Figure 3).

Table 3 presents the level of evidence of effects considered to be adverse, based on available findings listed in Tables 1 and 2. We provide indications of evidence as to whether an effect requires more research on the greenhouse- or field-scale level and/or whether it should be part of the PMEM carried out on the landscape scale. The indication of relevant scale levels depends on the type of effect or indicator group to be investigated (Graef et al., 2005b; Hilbeck et al., 2008b). In general, the larger the scale of investigation, the more ecological relevance applies to an effect or indicator and the more challenging the risk management or control (Figure 1). Some adverse effects such as invasiveness can be detected, if ever, only at larger scales. Furthermore, the larger the scale of investigation, the more challenging the experimental design and the less likely that standardised detection methods exist. Findings on the laboratory or greenhouse scale are not easily reproduced and/or confirmed on the field scale. Reasons include a) their poor relevance at larger scales due to higher variations and multiple influences of environmental factors, b) a lack of suitable field detection methods, or c) a poor statistical design. Based on our findings in Sections 3, 4, and 5, we outline research shortcomings at three different scale levels.

Living Reviews in Landscape Research

http://www. livingreviews.org/lrlr-2010-3 


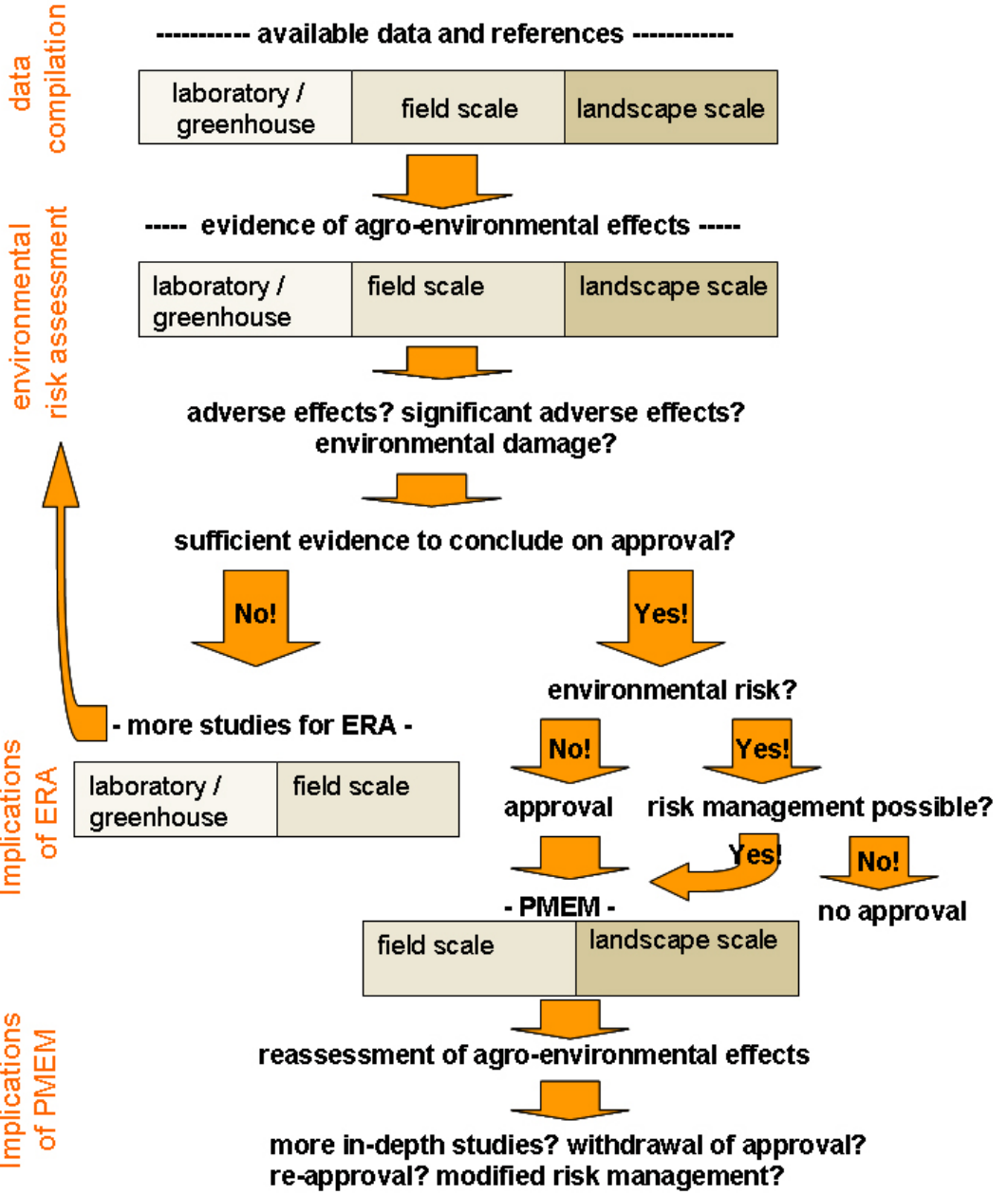

Figure 3: Pathways for ERA and PMEM and relevance of scales. 
Table 3: Evidence of potential adverse agro-environmental effects and relevance for ERA and PMEM at different scale levels.

\begin{tabular}{|c|c|c|}
\hline Evidence $^{1}$ & Potential adverse agro-environmental effects ${ }^{1}$ & Research and/or PMEM \\
\hline \multicolumn{3}{|c|}{ Field scale (limited in time and scale) } \\
\hline high & $\begin{array}{l}\text { glyphosate use } \rightarrow \text { adverse effects on field organisms } \\
\text { and/or aquatic communities in cropped fields and neigh- } \\
\text { bouring habitats }\end{array}$ & $\begin{array}{l}\text { examine adverse effects on field } \\
\text { organisms and aquatic communi- } \\
\text { ties / PMEM (CSM) }\end{array}$ \\
\hline high & $\begin{array}{l}\text { glyphosate use } \rightarrow \text { adverse effects on soil fungal commu- } \\
\text { nities, diseases and nutrient availability }\end{array}$ & $\begin{array}{l}\text { examine adverse effects on fungal } \\
\text { communities / PMEM (CSM) }\end{array}$ \\
\hline medium & $\begin{array}{l}\text { change in spray schedules of insecticides and fungicides } \\
\rightarrow \text { implications for microbial and/or fauna activities }\end{array}$ & $\begin{array}{l}\text { examine possible adverse effects } \\
\text { for microbial and/or fauna activi- } \\
\text { ties / PMEM (GS) }\end{array}$ \\
\hline medium & $\begin{array}{l}\text { changes in tillage system } \rightarrow \text { implications for soil degra- } \\
\text { dation and erosion }\end{array}$ & $\begin{array}{l}\text { examine possible adverse effects } \\
\text { on soil degradation and erosion / } \\
\text { PMEM (GS) }\end{array}$ \\
\hline medium & $\begin{array}{l}\text { transgene may be transferred via horizontal gene trans- } \\
\text { fer to other species such as bacteria }\end{array}$ & $\begin{array}{l}\text { examine likelihood and possible } \\
\text { adverse effects of horizontal gene } \\
\text { transfer }\end{array}$ \\
\hline low & $\begin{array}{l}\text { stable weed beet populations } \rightarrow \text { unpredictable combina- } \\
\text { tory effects with cultivated and/or wild relatives }\end{array}$ & $\begin{array}{l}\text { investigate possible adverse com- } \\
\text { binatory effects }\end{array}$ \\
\hline low & $\begin{array}{l}\text { pleiotropic and epigenetic genome effects of HR sugar } \\
\text { beet }\end{array}$ & $\begin{array}{l}\text { investigate possible adverse } \\
\text { pleiotropic and epigenetic genome } \\
\text { effects }\end{array}$ \\
\hline low & changed quality of plant parts & $\begin{array}{l}\text { investigate possible adverse } \\
\text { changes / PMEM (GS) }\end{array}$ \\
\hline low & effects on various soil functions & $\begin{array}{l}\text { investigate possible adverse effects } \\
\text { on soil functions }\end{array}$ \\
\hline
\end{tabular}

Continued on next page... 
Table 3 - Continued

\begin{tabular}{|c|c|c|}
\hline Evidence $^{1}$ & Potential adverse agro-environmental effects ${ }^{1}$ & Research and/or PMEM \\
\hline \multicolumn{3}{|c|}{ Landscape scale } \\
\hline high & $\begin{array}{l}\text { glyphosate use } \rightarrow \text { higher concentrations in surface } \\
\text { and ground waters neighbouring fields treated with } \\
\text { glyphosate }\end{array}$ & $\begin{array}{l}\text { PMEM (CSM) of increased } \\
\text { glyphosate concentrations in } \\
\text { aquatic ecosystems }\end{array}$ \\
\hline high & $\begin{array}{l}\text { in case of bolters and groundkeepers flowering } \rightarrow \mathrm{HR} \\
\text { seed production } \rightarrow \text { stable HR seed bank }\end{array}$ & $\begin{array}{l}\text { bolter and volunteer monitor- } \\
\text { ing and eradication according to } \\
\text { agric. practice }\end{array}$ \\
\hline high & $\begin{array}{l}\text { in case of bolters and groundkeepers flowering } \rightarrow \text { hy- } \\
\text { bridisation with neighbouring cultivated, feral and weed } \\
\text { beets }\end{array}$ & $\begin{array}{l}\text { PMEM (GS) of possibly persist- } \\
\text { ing or invasive HR beets }\end{array}$ \\
\hline high & $\begin{array}{l}\text { in case of bolters and groundkeepers flowering } \rightarrow \text { hy- } \\
\text { bridisation with wild relatives }\end{array}$ & $\begin{array}{l}\text { PMEM (GS) of possibly persist- } \\
\text { ing or invasive wild HR relatives }\end{array}$ \\
\hline high & $\begin{array}{l}\text { increase of HR in sugar beet seed bank } \rightarrow \text { hybridisation } \\
\text { with neighbouring cultivated and/or wild relatives } \rightarrow \text { in } \\
\text { case of a selective advantage and/or genetic drift: HR } \\
\text { sugar beet and related species may persist and become } \\
\text { invasive }\end{array}$ & $\begin{array}{l}\text { PMEM (GS) of possible in- } \\
\text { crease of HR beet, hybridised } \\
\text { HR species and/or transgene in } \\
\text { the environment }\end{array}$ \\
\hline high & development of HR in weeds & $\begin{array}{l}\text { PMEM (CSM) of possibly in- } \\
\text { creased HR in weeds }\end{array}$ \\
\hline high & $\begin{array}{l}\text { control of increased HR in weeds } \rightarrow \text { increased ai amount, } \\
\text { different types of herbicides, higher spraying frequency } \\
\rightarrow \text { various adverse effects on field organisms and/or soil } \\
\text { bio-geochemical cycles }\end{array}$ & $\begin{array}{l}\text { PMEM (CSM) of herbicide appli- } \\
\text { cation regime and adverse effects } \\
\text { on field organisms and soil func- } \\
\text { tions }\end{array}$ \\
\hline high & $\begin{array}{l}\text { increased weed suppression } \rightarrow \text { less biomass, food, flowers } \\
\text { and habitats for field organisms after spraying } \rightarrow \text { lower } \\
\text { abundance of various herbivores, pollinators and bene- } \\
\text { ficial species (pest antagonists) } \rightarrow \text { effects on depending } \\
\text { organisms / food web } \rightarrow \text { decrease in agrobiodiversity }\end{array}$ & $\begin{array}{l}\text { PMEM (CSM) of possible de- } \\
\text { crease in agrobiodiversity }\end{array}$ \\
\hline high & $\begin{array}{l}\text { decrease and/or shift of weedy species and weed seed } \\
\text { bank }\end{array}$ & $\begin{array}{l}\text { PMEM (GS) of adverse effects } \\
\text { of decrease of weedy species and } \\
\text { weed seed bank }\end{array}$ \\
\hline medium & reduced crop rotation options & $\begin{array}{l}\text { PMEM (GS) of long-term sus- } \\
\text { tainability of cropping systems }\end{array}$ \\
\hline medium & $\begin{array}{l}\text { post-emergent spraying } \rightarrow \text { increased drift and pollution } \\
\text { due to higher late-season wind speeds and/or increased } \\
\text { spraying height }\end{array}$ & $\begin{array}{l}\text { PMEM (GS) of increased herbi- } \\
\text { cide drift and pollution }\end{array}$ \\
\hline medium & $\begin{array}{l}\text { coexistence measures to reduce vertical gene flow } \rightarrow \\
\text { reduced crop rotation options } \rightarrow \text { various positive or neg- } \\
\text { ative implications for field organisms and/or soil bio- } \\
\text { geochemical cycles }\end{array}$ & $\begin{array}{l}\text { PMEM (GS) of long-term sus- } \\
\text { tainability of cropping systems }\end{array}$ \\
\hline low & possible impact on migratory and mobile species & $\begin{array}{l}\text { PMEM (GS) of potential adverse } \\
\text { effects on migratory and mobile } \\
\text { species }\end{array}$ \\
\hline low & $\begin{array}{l}\text { control of HR sugar beet volunteers in followcrops } \rightarrow \\
\text { reduced crop rotation options (e.g., wider rotations or } \\
\text { crops with other HR traits) } \rightarrow \text { possible implications for } \\
\text { field organisms and soil bio-geochemical cycles }\end{array}$ & $\begin{array}{l}\text { PMEM (GS) of possible adverse } \\
\text { effects on field organisms and soil } \\
\text { functions }\end{array}$ \\
\hline low & $\begin{array}{l}\text { stable weed populations } \rightarrow \text { adverse effects on neighbour- } \\
\text { ing habitats such as ecosystem food chains; impacts on } \\
\text { biodiversity }\end{array}$ & $\begin{array}{l}\text { PMEM (GS) of ecosystem food } \\
\text { chain effects and biodiversity }\end{array}$ \\
\hline
\end{tabular}

\footnotetext{
${ }^{1}$ References see Table 1 and 2
} 
Laboratory or greenhouse scale: Lab or greenhouse experiments on the GM crop can involve survivability, genetic stability, as well as interactions with target and NTOs and the abiotic environment. Such experiments are a regular part of the GM crop development process. However, in general data on potential environmental effects of the GMHT sugar beet are few, inadequate or missing. Additionally, experimental results lack a sound statistical design and thus are not or hardly reproducible. For the acute toxicity tests in the risk assessment of NTOs we suggest to use the whole GM plant material instead of isolated microbially produced transgene products that are usually provided. We suggest prolonged ecotoxicity tests (Hilbeck et al., 2008a), since in reality NTOs may be exposed over longer periods, for example one or several life stages or even over the whole life cycle. Moreover, they are exposed to the complete plant material of the GMP, not only to single substances. We also recommend incorporating realistic exposure pathways when testing NTOs (Römbke et al., 2010). So far, the selection of test organisms is poorly founded. For instance, tests with insect pests of other crop species such as the European corn borer and the Colorado potato beetle are a questionable choice for investigating effects of a GMHR sugar beet on NTOs.

Field scale (limited in time and space): For the field scale, we suggest further experiments of adverse effects of a) the GMP and b) different glyphosate formulations on various trophic levels of field organisms, aquatic communities and soil microbial communities. The latter should focus on specific effects caused by the changed time frame of glyphosate spraying in GMHR sugar beet. To differentiate between herbicide effects and possible pleiotropic effects, part of the experiments should exclude pesticide application. Further research and more information for the ERA is also required on possible adverse effects for microbial and/or faunal activities and on soil degradation. Irrespective of the HR sugar beet, the relevance and potential adverse effects of horizontal gene transfer should be further clarified. Only little is known about possible combinatory effects after hybridisation and about pleiotropic and epigenetic genome effects of the HR sugar beet. More information is also required about potentially altered quality of plant parts after years of cultivation and about possible effects on various soil functions of the HR sugar beet.

Landscape scale: For the landscape scale, we suggest the CSM of possibly increased glyphosate formulation concentrations in soils and aquatic ecosystems as an indicator for adverse effects on field organisms and aquatic communities. Observation and eradication of sugar beet bolters and volunteers is usual agricultural practice. In some places and/or in some years, bolters or volunteers may be either overlooked or too frequent to overcome. This may lead to HR pollen flow, hybridisation with neighbouring beets and wild relatives, seed production and seed shed. We suggest the GS of possible persistence and invasiveness (triggered by a possible selective advantage and/or genetic drift) for HR cultivated, feral and weed beets, hybridised HR related species and/or the transgenes in the neighbouring environment. This applies especially to HR sugar beet seed production regions. A CSM is recommended for detecting the likely increase of HR in weeds and subsequently the likely increase and/or change in the herbicide application regime after several years of glyphosate application. A further recommendation is the CSM of the possible HR-related decrease in agrobiodiversity, including weed communities, herbivores, pollinators and beneficial species. GS should be done of the long-term sustainability of cropping systems and their rotations as well as of a potentially increased herbicide drift and pollution. Although current evidence is poor for potential adverse effects on migratory and mobile species, on soil functions and ecosystem food chain effects, and on larger scale biodiversity, literature findings do suggest GS of these issues.

Living Reviews in Landscape Research

http://www. livingreviews.org/lrlr-2010-3 


\section{$7 \quad$ A step-by-step scale approach for HR sugar beet?}

The European Commission (2001) regulations require a step-by-step procedure for GM crop market approval that includes experimental data at the field scale to predict the outcome of larger landscape-scale release (Figure 1). Our review of available references on the one hand indicates various potential and demonstrated adverse environmental effects and, on the other, a lack of well-designed experimental data and/or other information with environmental relevance. The references screened refer to different spatial scales. They firstly enable an assessment of environmental hazards, and/or secondly should trigger further experimental field-scale activities, and/or thirdly should be the basis for a landscape scale-based PMEM, either CSM or GS (Figure 3).

In GM crop approval practice, as in society in general, the conclusions on adverse effects and on their significance vary. This also pertains to subsequent requirements such as further experimental research, CSM or GS. Ultimately, however, decisions should be science-based, implying the use of data with sound statistical design and power (European Commission, 2001). Lövei and Arpaia (2005) and Perry et al. (2009) state that field studies for the ERA often lack such statistical design and power. Studies with NTOs to check for unexpected direct and/or indirect effects as previewed also by GMO Panel (2010) are largely missing.

Test species for NTOs risk assessment should be selected using a systematic, transparent, scientifically based and stepwise methodology as developed by the GMO ERA Guideline Project (Hilbeck and Andow, 2004; Hilbeck et al., 2006; Andow et al., 2008) and as refined by Hilbeck et al. (2008a). Furthermore, field sites for NTO testing should be selected to be representative for the receiving environments relevant to the market release as developed by Jänsch et al. (2010). Field studies should use plant material from the GMP and be performed in the laboratory, greenhouse or at the semi-field level, and in the field.

To date, the ERA in the application dossiers usually relies on tests originally developed and standardised for chemicals. These tests frequently do not examine the whole GM plants but only specific transgene products. Although this ecotoxicological testing concept is widely used, it does not fulfil the requirements of the Directive 2001/18/EC. A harmonised concept for ecotoxicological testing considering the whole GM plant characteristics is recommended, for example as outlined by Römbke et al. (2010). Furthermore, we recommend a more in-depth examination as to whether experimental data on specific potential adverse effects of GMHR sugar beet cultivation are scientifically-based and statistically sufficient to be upscaled (Breckling et al., 2009; Squire et al., 2009).

A general barrier to premarket tests and field studies is the research and publication control by GM seed companies. Under the threat of litigation, user agreements explicitly exclude the use of the seeds for any independent research (Waltz, 2009; Scientific American eds., 2009), and experimental results must be approved by the companies before being published. Thus, experimental data exhibiting potential adverse effects may not be made public and cannot enter the ERA process.

If potential adverse effects identified in the ERA are selected for further PMEM (Figure 3), this also requires statistical multi-scale designs (Firbank et al., 2003; Stein and Ettema, 2003); this includes determining the environmental baseline status (European Commission, 2002) to identify adverse effects in a CSM and in GS. Science-based PMEM approaches are available (Graef et al., 2005a,b; Züghart et al., 2008) and should be carried out in a coordinated and harmonised way (Finck et al., 2006; Graef et al., 2008). The PMEM requires both static and flexible elements because agricultural systems are dynamic. They need to be adaptive as new information emerges (Lindemayer and Likens, 2009) and should feed back on the ERA as monitoring data becomes available. 


\section{Conclusions}

A stepwise increase of release scale, based on results from a gradually enhanced data base, is a precautionary principle required through Directive 2001/18/EC. The foundation to ensure this principle is to collect sufficient data during lab, greenhouse experiments and field trials. This is the only approach that enables a solid environmental risk assessment and the subsequent planning and design of the post-market environmental monitoring. It is crucial in helping to detect possible larger-scale and long-term effects and to avoid possible environmental damage.

For the GMHR sugar beet as a case study, we identified shortcomings in the presently available information for the environmental risk assessment at all levels of spatial scales: On the laboratory scale, data on potential environmental effects are few, inadequate or missing, and/or statistical designs of experiments are poor. Ecotoxicity tests for non-target organisms are too short-lived and do not use the real GMHR sugar beet material. Finally, the selection of test organisms is questionable. On the field scale, further experiments are required on adverse effects of GMHR sugar beet and different glyphosate formulations on various trophic levels of field organisms, aquatic communities and soil microbial communities. We therefore argue that more research experiments should be done initially to enable completing the environmental risk assessment.

Once approved, a case-specific monitoring should be carried out for a) possibly increased glyphosate formulation concentrations in soils and aquatic ecosystems, b) adverse effects on field organisms and aquatic communities, c) herbicide resistance in weeds, d) the possible increase and/or change in the herbicide application regime after years of glyphosate application, and e) a possible decrease in agrobiodiversity (weed communities, herbivores, pollinators and beneficial species) linked to the HR technology. General surveillance should be carried out on a) possible persistence and invasiveness of HR cultivated, feral and weed beets, and hybridised HR-related species in the agro-environment, b) sustainability of cropping systems and their rotations, c) potentially increased herbicide drift and pollution, and d) potential adverse effects on migratory and mobile species, soil functions, ecosystem food chain effects, and large-scale biodiversity.

\section{Acknowledgements}

Funding from the Federal Ministry of Food, Agriculture and Consumer Protection (BMELV) and the Ministry of Infrastructure and Agriculture (MIL) Brandenburg has supported this work. Thanks to M. Stachowitsch for improving the English and to two anonymous reviewers for their valuable comments.

\section{Acronyms}

$\begin{array}{ll}\text { Ai } & \text { active ingredient } \\ \text { HR } & \text { herbicide-resistant / herbicide resistance } \\ \text { GM } & \text { genetically modified } \\ \text { GMO } & \text { genetically modified organism } \\ \text { GMHR } & \text { genetically modified herbicide-resistant } \\ \text { ERA } & \text { environmental risk assessment } \\ \text { PMEM } & \text { post market environmental monitoring } \\ \text { NTO } & \text { non-target organism }\end{array}$

Living Reviews in Landscape Research

http://www. livingreviews . org/lrlr-2010-3 


\section{References}

ACRE (2004), "Guidance on best practice in the design of post-market monitoring plans in submissions to the Advisory Committee on Releases to the Environment", ACRE Guidance Note, 16, London (Department for Environment, Food and Rural Affairs). Online version (accessed 04 August 2010):

http: //webarchive.nationalarchives.gov.uk/20080727101330/http://www.defra.gov . uk/environment/acre/postmarket/index.htm. (Cited on pages 5 and 6.)

"Agronomy Guide 2009-2010" (2010), online resource, Pennsylvania State University. URL (accessed 04 August 2010):

http://agguide.agronomy.psu.edu/. (Cited on pages 12, 15, and 17.)

Andow, D.A. and Hilbeck, A. (2004), "Science-Based Risk Assessment for Nontarget Effects of Transgenic Crops", BioScience, 54(7): 637-649, [DOI]. (Cited on page 5.)

Andow, D.A., Hilbeck, A. and Nguyen, V.T., eds. (2008), Challenges and Opportunities with Bt Cotton in Vietnam, Environmental Risk Assessment of Genetically Modified Organisms, 4, Wallingford, UK; Cambridge, MA (CABI). (Cited on page 23.)

Arnaud, J.-F., Viard, F., Delescluse, M. and Cuguen, J. (2003), "Evidence for gene flow via seed dispersal from crop to wild relatives in Beta vulgaris (Chenopodiaceae), consequences for the release of genetically modified crop species with weedy lineages", Proceedings of the Royal Society of London, Series B: Biological Sciences, 270: 1565-1571, [DOI]. (Cited on pages 11 and 12.)

Arnaud, J.-F., Fénart, S., Godé, C., Deledicque, S., Touzet, P. and Cuguen, J. (2009), "Fine-scale geographical structure of genetic diversity in inland wild beet populations", Molecular Ecology, 18: 3201-3215, [DOI]. (Cited on page 11.)

Bailey, R.G. (2002), Ecoregion-Based Design for Sustainability, New York (Springer). Google Books. (Cited on page 7.)

Bartsch, D. and Schmidt, M. (1997), "Influence of sugar beet breeding on populations of Beta vulgaris ssp. maritima in Italy", Journal of Vegetation Science, 8: 81, [DOI]. (Cited on page 11.)

Bartsch, D., Lehnen, M., Clegg, J., Pohl-Orf, M., Schuphan, I. and Ellstrand, N.C. (1999), "Impact of gene flow from cultivated beet on genetic diversity of wild sea beet populations", Molecular Ecology, 8: 1733, [DOI]. (Cited on pages 10, 11, and 14.)

Bartsch, D., Cuguen, J., Biancardi, E. and Sweet, J. (2003), "Environmental implications of gene flow from sugar beet to wild beet - current status and future research needs", Environmental Biosafety Research, 2(2): 105-115, [DOI]. (Cited on pages 5, 10, 11, and 12.)

Bartsch, D., Gathmann, A., Koziolek, C., Vaasen, A. and Buhk, H.-J. (2009), "Implication of the Environmental Liability Directive for General Surveillance - What to Protect?", Journal für Verbraucherschutz und Lebensmittelsicherheit, 3(Supplement 2): 8-11, [DOI]. (Cited on page 9.)

Bartz, R., Heink, U. and Kowarik, I. (2009), "Proposed definition of environmental damage illustrated by the cases of genetically modified crops and invasive species", Conservation Biology, 24 (3): 675-681, [DOI]. (Cited on pages 5, 6, 14, and 18.)

Beckie, H.J. (2006), "Herbicide-resistant weeds: Management tactics and practices", Weed Technology, 20: 793-814, [DOI]. (Cited on page 11.) 
Beckie, H.J., Harker, K.N., Hall, S.I., Légère, A., Sikkema, P.H., Clayton, G.W., Thomas, A.G., Leeson, J.Y., Ségiun-Swartz, G. and Simard, M.J. (2006), "A decade of herbicide-resistant crops in Canada", Canadian Journal of Plant Science, 86: 1243. (Cited on pages 12 and 17.)

Benachour, N. and Séralini, G.E. (2009), "Glyphosate formulations induce apoptosis and necrosis in human umiblical, embryonic, and placental cells", Chemical Research in Toxicology, 22: 97-105, [DOI]. (Cited on pages 5, 14, 15, and 17.)

Benbrook, C. (2009), "Impacts of Genetically Engineered Crops on Pesticide Use: The First Thirteen Years", Boulder, CO (The Organic Center). URL (accessed 04 August 2010):

http://www.organic-center.org/science.pest.php?action=view\&report_id=159. (Cited on pages 12 and 17.)

Benton, T.G., Bryant, D.M., Cole, L. and Crick, H.Q.P. (2002), "Linking agricultural practice to insect and bird populations: a historical study over three decades", Journal of Applied Ecology, 39: 673-687, [DOI]. (Cited on pages 14 and 17.)

BfN (2010), "Natura 2000-Gebiete für Antragsteller von GVO-Freisetzungen", web interface to database, Bundesamt für Naturschutz. URL (accessed 03 August 2010):

http://www.bfn.de/0503_einstieg_gvo.html. (Cited on page 9.)

Bohan, D.A., Boffey, W.H., Brooks, D.R., Clark, S.J., Dewar, A.M., Firbank, L., Haughton, A.J., Hawes, C., Heard, M.S., May, M.J., Osborne, J.L., Perry, J.N., Rothery, P., Roy, D.B., Scott, R.J., Squire, G.R., Woiwod, I.P. and Champion, G.T. (2005), "Effects on weed and invertebrate abundance and diversity of herbicide-tolerant winter-sown oilseed rape", Proceedings of the Royal Society of London, Series B: Biological Sciences, 272: 463-474, [DOI]. (Cited on pages 14 and 17.)

Boudry, P., Mörchen, M., Saumitou-Laparde, P., Vernet, P. and Van Dijk, H. (1993), "The origin and evolution of weed beets: consequences for the breeding and release of herbicide-resistant transgenic sugar beets", Theoretical and Applied Genetics, 87: 471-478, [DOI]. (Cited on page 11.)

Brausch, J.M. and Smith, P.N. (2007), "Toxicity of three polyethoxylated tallowamine surfactant formulations to laboratory and field collected fairy shrimp, Thamnocephalus platyurus", Archives of Environmental Contamination and Toxicology, 52(2): 217-221, [DOI]. (Cited on pages 5 and 15.)

Breckling, B., Reuter, H., Middelhoff, U., Glemnitz, M., Wurbs, Schmidt, G., Schröder, W. and Windhorst, W. (2009), "Risk indication of genetically modified organisms (GMO): Modelling environmental exposure and dispersal across different scales: Oilseed rape in Northern Germany as an integrated case study", Ecological Indicators, in press, [DOI]. (Cited on pages 6 and 23.)

Buddemeyer, J. and Petersen, J. (2002), "Reproduction potential of seedborne weed beet and sugar beet harvest residues", in Proceedings of the 65th IIRB Congress, Brussels, 13 - 14 February 2002, pp. 407-412, Brussels (International Institute for Beet Research). (Cited on pages 10 and 11.)

Burkett, E. (2010), "Safety of GM Sugar Beets Subject of Hearing", online resource, Food Safety News. URL (accessed 04 August 2010):

http://www.foodsafetynews.com/2010/01/safety-of-gm-sugar-beets-subject-of-hearing/. (Cited on page 5.)

BVL (2007), "Erläuterungen zu den Dateien des Monsanto MON810 Monitoring und Implementierungsplan", online resource, Bundesamt für Verbraucherschutz. URL (accessed 04 August

Living Reviews in Landscape Research

http://www. livingreviews.org/lrlr-2010-3 
2010):

http://www.bvl.bund.de/cln_027/nn_491658/DE/08__PresseInfothek/00__doks_ _downloads/Monitoringplan.html. (Cited on page 5.)

Cerdeira, A.L. and Duke, S.O. (2006), "The current status and environmental impact of glyphosateresistant crops: a review", Journal of Environmental Quality, 35: 1633-1658, [DOI]. (Cited on pages $11,14,15$, and 17.)

Champion, G.T. and May, M.J. (2004), "GMHT use in oilseed rape - opportunities for weed management and implications for wildlife and rotations", in van Emden, H.F. and Gray, A.J., eds., GM Crops - Ecological Dimensions, Aspects of Applied Biology, 74, pp. 197-205, Wellesbourne, UK (The Association of Applied Biologists). (Cited on page 17.)

Champion, G.T., May, M.J., Bennett, S., Brooks, D.R., Clark, S.J., Daniels, R.E., Firbank, L.G., Haughton, A.J., Hawes, C., Heard, M.S., Perry, J.N., Randle, Z., Rossall, M.J., Rothery, P., Skellern, M.P., Scott, R.J., Squire, G.R. and Thomas, M.R. (2003), "Crop management and agronomic context of the Farm Scale Evaluations of genetically modified herbicide-tolerant crops", Philosophical Transactions of the Royal Society of London, Series B, 358: 1801-1818. (Cited on pages 12,15 , and 17.)

De Bock, T.S.M. (1986), "The genus Beta: Domestication, taxonomy and interspecific hybridisation for plant breeding", in van der Maesen, L.J.G., ed., I International Symposium on Taxonomy of Cultivated Plants, Wageningen, The Netherlands, Acta Horticulturae, 182, pp. 335-344, Leuven (ISHS). (Cited on page 11.)

De Jong, T. (2010), "General surveillance of genetically modified plants in the EC3 and the need for controls", Journal für Verbraucherschutz und Lebensmittelsicherheit, 5: 181-183, [DOI]. (Cited on page 6.)

De Schrijver, A., Devos, Y., Van den Bulck, M., Cadot, P., De Loose, M., Reheul, D. and Sneyers, M. (2007), "Risk assessment of GM stacked events obtained from crosses between GM events", Trends in Food Science \& Technology, 18: 101-109, [DOI]. (Cited on page 6.)

Desplanque, B., Hautekèete, N. and Van Dijk, H. (2002), "Transgenic weed beets: possible, probable, avoidable?", Journal of Applied Ecology, 39: 561-571, [DOI]. (Cited on pages 11 and 12.)

Dewar, A.M., Haylock, L.A., Bean, K.M. and May, M.J. (2000), "Deleayed control of weeds in glyphosate-tolerant sugar beet and the consequences on aphid infestation and yield", Pest Management Science, 56: 345-350, [DOI]. (Cited on page 15.)

Dolezel, M., Miklau, M., Eckersdorfer, M., Hilbeck, A., Heissenberger, A. and Gaugitsch, H. (2009), "Standardising the Environmental Risk Assessment of Genetically Modified Plants in the EU", BfN-Skripten, 259, Bonn (Bundesamt für Naturschutz). URL (accessed 03 August 2010): http://www.bfn.de/0502_skripten.html. (Cited on pages 5, 6, and 8.)

Drießen, S., Pohl, M. and Bartsch, D. (2001), "RAPD-PCR analysis of the genetic origin of sea beet (Beta vulgaris ssp. maritima) at Germany's Baltic Sea coast", Basic and Applied Ecology, 2: 341, [DOI]. (Cited on pages 11 and 14.)

EFSA (2008), "The ESFA Scientific Report, Annex A: Updated Guidance Document for the Risk Assessment of Genetically Modified Plants and Derived Food and Feed", EFSA Journal, EFSAQ-2003-005E, Parma (European Food Safety Authority). URL (accessed 04 August 2010): http://www.efsa.europa.eu/en/scdocs/scdoc/293r.htm. (Cited on pages 5 and 7.) 
Eiden, G., Kayadjanian, M. and Vidal, C. (2000), "Quantifying Landscape Structures: spatial and temporal dimensions", in From Land Cover to Landscape Diversity in the European Union, Brussels (The European Commission). URL (accessed 03 August 2010): http://ec.europa.eu/agriculture/publi/landscape/ch2.htm. (Cited on page 7.)

Elliott, M.C. and Weston, G.D. (1993), "Biology and physiology of the sugar beet plant", in Cooke, D.A. and Scott, R.K., eds., The Sugar Beet Crop: Science into Practice, pp. 37-66, London (Chapman \& Hall). (Cited on pages 10 and 11.)

EU Monitoring Working Group (2010), "Applicability of existing EU monitoring programmes and data infrastructure schemes for GMO monitoring and options for implementing data coordination and harmonisation", Brussels (European Commission). Unpublished report. (Cited on page 6.)

European Commission (1991), "Council Directive 91/414/EEC of 15 July 1991 concerning the placing of plant protection products on the market", Official Journal of the European Communities, 20(L230): 1-32, Luxembourg (Publications Office). Online version (accessed 04 August 2010):

http: //eur-lex . europa . eu/LexUriServ/LexUriServ .do?uri=CELEX : 31991L0414 : EN : NOT.

(Cited on page 9.)

European Commission (2001), "Directive 2001/18/EC of the European Parliament and of the Council of 12 March 2001 on the deliberate release into the environment of genetically modified organisms and repealing Council Directive 90/220/EEC", Official Journal of the European Communities, 44(L106): 1-39, Luxembourg (Publications Office). Online version (accessed 03 August 2010):

http://eur-lex.europa.eu/JOHtml.do?uri=0J:L:2001:106:SOM:EN:HTML. (Cited on pages 5,8 , and 23.)

European Commission (2002), "Council Decision of 3 October 2002 establishing guidance notes supplementing Annex VII to Directive 2001/18/EC of the European Parliament and of the Council on the deliberate release into the environment of genetically modified organisms and repealing Council Directive 90/220/EEC", Official Journal of the European Communities, 45 (L280): 27-36, Luxembourg (Publications Office). Online version (accessed 03 August 2010): http://eur-lex.europa.eu/JOHtml.do?uri=0J:L:2002:280:SOM:EN:HTML. (Cited on pages 5,7 , and 23.)

European Commission (2003), "Commission Recommendation of 23 July 2003 on guidelines for the development of national strategies and best practices to ensure the coexistence of genetically modified crops with conventional and organic farming (notified under document number C(2003) 2624)", Official Journal of the European Communities, 46(L189): 36-47, Luxembourg (Publications Office). Online version (accessed 04 August 2010):

http://eur-lex.europa.eu/JOHtml.do?uri=0J:L:2003:189:SOM:EN:HTML. (Cited on page 13.)

Fernandez, M.R., Zentner, R.P., Basnyat, P., Gehl, D., Selles, F. and Huber, D. (2009), "Glyphosate associations with cereal diseases caused by Fusarium spp. in the Canadian Prairies", European Journal of Agronomy, 31(3): 133-143, [DOI]. (Cited on pages 14 and 17.)

Finck, M., Seitz, H. and Beismann, H. (2006), "Concepts for General Surveillance: VDI Proposals Standardisation and Harmonisation in the Field of GMO-Monitoring", Journal für Verbraucherschutz und Lebensmittelsicherheit, 1(Supplement 1): 11-14, [DOI]. (Cited on pages 6 and 23.)

Firbank, L.G. and Forcella, F. (2000), "Genetically Modified Crops and Farmland Biodiversity", Science, 289: 1481-1482, [DOI]. (Cited on page 17.)

Living Reviews in Landscape Research

http: //www. livingreviews.org/lrlr-2010-3 
Firbank, L.G., Heard, M.S., Woiwod, I.P., Hawes, C., Haughton, A.J., Champion, G.T., Scott, R.J., Hill, M.O., Dewar, A.M., Squire, G.R., May, M.J., Brooks, D.R., Bohan, D.A., Daniels, R.E., Osborne, J.L., Roy, D.B., Black, H.I.J., Rothery, P. and Perry, J.N. (2003), "An introduction to the Farm-Scale Evaluations of genetically modified herbicide-tolerant crops", Journal of Applied Ecology, 40: 2-16, [DOI]. (Cited on pages 6 and 23.)

Firbank, L.G., Rothery, P., May, M.J., Clark, S.J., Scott, R.J., Stuart, R.C., Boffey, C.W.H., Brooks, D.R., Champion, G.T., Haughton, A.J., Hawes, C., Heard, M.S., Dewar, A.M., Perry, J.N. and Squire, G.R. (2006), "Effects of genetically modified herbicide-tolerant cropping systems on weed seedbanks in two years of following crops", Biology Letters, 2(1): 140-142, [DOI]. (Cited on page 17.)

Frese, L. (1998), "Praktisches Genpoolmanagement bei einem Fremdbefruchter - Zuckerrüben und verwandte Wildarten", in Begemann, F., ed., Züchterische Nutzung pflanzengenetischer Ressourcen: Ergebnisse und Forschungsbedarf, Tagungsband eines Symposiums vom 29.09. bis 01.10.1997 in Gatersleben, Schriften zu Genetischen Ressourcen, 8, pp. 26-38, Bonn (ZADI). Online version (accessed 04 August 2010):

http://www.genres.de/service/publikationen-informationsmaterial/

schriftenreihe/. (Cited on pages 10,11, and 14.)

Frese, L., Desprez, B. and Ziegler, D. (2001), "Potential of genetic resources and breeding strategies for base-broadening in Beta", in Cooper, H.D., Spillane, C. and Hodgkin, T., eds., Broadening the Genetic Base of Crop Production, pp. 295-309, Wallingford, U.K. (CABI). Online version (accessed 04 August 2010):

http://www.ecpgr.cgiar.org/Workgroups/beta/article_Beta.pdf. (Cited on pages 11 and 12.)

Frick, B. and Thomas, A.G. (1992), "Weed surveys in different tillage systems in south-western Ontario field crops", Canadian Journal of Plant Science, 72: 1337-1347. (Cited on pages 14 and 17.)

Geisler, G. (1980), Pflanzenbau: Ein Lehrbuch - Biologische Grundlagen und Technik der Pflanzenproduktion, Berlin; Hamburg (Paul Parey). (Cited on pages 10 and 11.)

GMO Panel (2010), "Scientic Opinion on the assessment of potential impacts of genetically modified plants on non-target organisms", EFSA Journal, Parma (European Food Safety Authority). URL (accessed 04 August 2010):

http://www.efsa.europa.eu/en/efsajournal.htm. In press. (Cited on pages 14 and 23.)

Graef, F. (2009), "Review: Potential environmental effects of altering cultivation practice with genetically modified herbicide-tolerant oilseed rape and implications for monitoring", Agronomy for Sustainable Development, 29: 31-42, [DOI]. (Cited on pages 5, 9, 11, 12, 14, 15, and 17.)

Graef, F., Schmidt, G., Schröder, W. and Stachow, U. (2005a), "Determining Ecoregions for GMO monitoring networks", Environmental Monitoring and Assessment, 108(1-3): 189-203, [DOI]. (Cited on pages 5 and 23.)

Graef, F., Züghart, W., Hommel, B., Heinrich, U., Stachow, U. and Werner, A. (2005b), "Methodological scheme for designing the monitoring of genetically modified crops at the regional scale", Environmental Monitoring and Assessment, 111(1-3): 1-26, [DOI]. (Cited on pages 5, 6, 7, 18, and 23.) 
Graef, F., De Schrijver, A. and Murray, B. (2008), "GMO monitoring data coordination and harmonisation at the EU level - Outcomes of the European Commission Working Group on Guidance Notes supplementing Annex VII of Directive 2001/18/EC", Journal für Verbraucherschutz und Lebensmittelsicherheit, 3(Supplement 2): 17-20, [DOI]. (Cited on pages 6 and 23.)

Hails, R S (2002), "Assessing the risks associated with new agricultural practices", Nature, 418: 685, [DOI]. (Cited on page 9.)

Heap, I. [Herbicide Resistance Action Committee (HRAC)] (2009), "The International Survey of Herbicide Resistant Weeds", project homepage, WeedScience. URL (accessed 04 August 2010): http://www. weedscience.org/. (Cited on page 5.)

Heard, M.S., Hawes, C., Champion, G.T., Clark, S.J., Firbank, L.G., Haughton, A.J., Parish, A.M., Perry, J.N., Rothery, P., Roy, B.A., Scott, R.J., Skellern, M.P., Squire, G.R. and Hill, M.O. (2003a), "Weeds in fields with contrasting conventional and genetically modified herbicidetolerant crops. II. Effects on individual species", Philosophical Transactions of the Royal Society of London, Series B, 358: 1833-1846, [DOI]. (Cited on pages 5, 12, 14, and 17.)

Heard, M.S., Hawes, C., Champion, G.T., Clark, S.J., Firbank, L.G., Haughton, A.J., Parish, A.M., Perry, J.N., Rothery, P., Scott, R.J., Skellern, M.P., Squire, G.R. and Hill, M.O. (2003b), "Weeds in fields with contrasting conventional and genetically modified herbicide-tolerant crops. I. Effects on abundance and diversity", Philosophical Transactions of the Royal Society of London, Series $B, 358$ : 1819-1832, [DOI]. (Cited on pages 5, 14, and 17.)

Heinemann, J.A. and Traavik, T. (2004), "Problems in monitoring horizontal gene transfer in field trials of transgenic plants", Nature Biotechnology, 22: 1105-1109, [DOI]. (Cited on pages 11 and 14.)

Heuer, H., Kroppenstedt, R.M., Lottmann, J., Berg, G. and Smalla, K. (2002), "Effects of T4 lysozyme release from transgenic potato roots on bacterial rhizospere communities are negligible relative to natural factors", Applied and Environmental Microbiology, 68(3): 1325-1335, [DOI]. (Cited on page 14.)

Hilbeck, A. and Andow, D.A., eds. (2004), Environmental Risk Assessment of Genetically Modified Organisms, Vol. 1: A Case Study of Bt Maize in Kenya, Wallingford, UK; Cambridge, MA (CABI). (Cited on page 23.)

Hilbeck, A., Andow, D.A. and Fontes, E.M.G., eds. (2006), Environmental Risk Assessment of Genetically Modified Organisms, Vol. 2: A Case Study of Bt Cotton in Brazil, Wallingford, UK; Cambridge, MA (CABI). (Cited on page 23.)

Hilbeck, A., Jänsch, S., Meier, M. and Römbke, J. (2008a), "Analysis and validation of present ecotoxicological test methods and strategies for the risk assessment of genetically modified plants", BfN-Skripten, 236, Bonn (Bundesamt für Naturschutz). URL (accessed 04 August 2010): http://www.bfn.de/0502_skripten.html. (Cited on pages 5, 22, and 23.)

Hilbeck, A., Meier, M. and Benzler, A. (2008b), "Identifying indicator species for post-release monitoring of genetically modified, herbicide resistant crops", Euphytica, 164(3): 903-912, [DOI]. (Cited on pages 5 and 18.)

Hole, D.G., Abdel-Baky, N.F., Perkins, A.J., Wilson, J.D., Alexander, I.H., Grice, P.V. and Evans, A.D. (2005), "Does organic farming benefit biodiversity?", Conservation Biology, 122: 113-130. (Cited on page 17.)

Living Reviews in Landscape Research

http://www. livingreviews . org/lrlr-2010-3 
Jänsch, S., Römbke, J., Hilbeck, A., Weiß, G., Teichmann, H. and Tappeser, B. (2010), "Classification of the receiving environment in the context of environmental risk assessment (ERA) of genetically modified plants (GMP) in Europe", BioRisk, submitted. (Cited on page 23.)

Johal, G.S. and Huber, D.M. (2009), "Glyphoste effects on diseases of plants", European Journal of Agronomy, 31(3): 144-152, [DOI]. (Cited on pages 14 and 17.)

Johnson, B. (2001), "A critical analysis of the field scale trials of herbicide tolerant oilseed rape in the UK, in EU-workshop: Monitoring of environmental impacts of genetically modified plants", in M., Miklau, H., Gaugitsch and A., Heissenberger, eds., EU-Workshop: Monitoring of Environmental Impacts of Genetically Modified Plants, EU-Workshop of the German Federal Environmental Agency 9th and 10th November, Berlin, 45/2001, pp. 142-148, Berlin (Umweltbundesamt). Online version (accessed 04 August 2010):

http://www. umweltbundesamt.de/uba-info-medien/publikationsliste-reihe-drucken. php. (Cited on pages 15 and 17.)

Johnson, K.L., Raybould, A.F., Hudson, M.D. and Poppy, G.M. (2007), "How does scientific risk assessment of GM crops fit within the wider risk analysis?", Trends in Plant Science, 12(1): 1-5, [DOI]. (Cited on page 5.)

Johnson, W.G., Davis, V.M., Kruger, G.R. and Weller, S.C. (2009), "Influence of glyphosateresistant cropping systems on weed species shifts and glyphosate-resistant weed populations", European Journal of Agronomy, 31(3): 162-172, [DOI]. (Cited on page 17.)

Jordan, D., Miles, R.J., Hubbard, V.C. and Lorenz, T. (2004), "Effect of management practices and cropping systems on earthworm abundance and microbial activity in Sanborn Field: a 115year-old agricultural field", Pedobiologia, 48: 99-110, [DOI]. (Cited on page 17.)

Keller, E.R., Hanus, H. and Heyland, K.-U. (1999), Knollen- und Wurzelfrüchte, Körner- und Futterleguminosen, Handbuch des Pflanzenbaus, 3, Stuttgart (Eugen Ulmer). (Cited on pages 10, 11, and 12.)

Kelly, D.W., Poulin, R., Tompkins, D.M. and Townsend, C.R. (2010), "Synergistic effects of glyphosate formulation and parasite infection on fish malformations and survival", Journal of Applied Ecology, 47: 498-504, [DOI]. (Cited on pages 14 and 17.)

Kleter, G.A., Bhula, R., Bodnaruk, K., Carazo, E., Felsot, A. S., Harris, C.A., Katayama, A., Kuiper, H.A., Racke, K.D., Rubin, B., Shevah, Y., Stephenson, G.R., Tanaka, K., Unsworth, J., Wauchope, R.D. and Wong, S. (2007), "Altered pesticide use on transgenic crops and the associated general impact from an environmental perspective", Pest Management Science, 63: 1107, [DOI]. (Cited on page 17.)

Krebs, J.R., Wilson, J.D., Bradbury, R.B. and Siriwardena, G.M. (1999), "The second Silent Spring?", Nature, 400: 611-612, [DOI]. (Cited on page 17.)

Kremer, R.J. and Means, N.E. (2009), "Glyphosate and glyphosate-resistant crop interactions with rhizosphere microorganisms", European Journal of Agronomy, 31(3): 153-161, [DOI]. (Cited on pages 14 and 17.)

Lange, W., Brandenburg, W.A. and De Bock, T.S. (1999), "Taxonomy and cultonomy of beet (Beta vulgaris L)", Botanical Journal of the Linnean Society, 130: 81, [DOI]. (Cited on pages 5 and 10.) 
Larson, R.L., Hill, A.L., Fenwick, A., Kniss, A.R., Hanson, L.E. and Miller, S.D. (2006), "Influence of glyphosate on Rhizoctonia and Fusarium root rot in sugar beet", Pest Management Science, 62: 1182-1192, [DOI]. (Cited on page 17.)

Légère, A. (2005), "Risks and consequences of gene flow from herbicide-resistant crops: canola (Brassica napus L) as a case study", Pest Management Science, 61(3): 292-300, [DOI]. (Cited on page 17.)

Lehnert, J. (2007), "Heute Schosser, morgen Unkrautrübe", Die Zuckerrübenzeitung, 2007(4): 10-11. Online version (accessed 04 August 2010):

http://www.vsz.de/contenido/cms/upload/DZZ/2007/04/Seite-10-11-Lehnert.pdf.

(Cited on page 11.)

Lindemayer, D.B. and Likens, G.E. (2009), "Adaptive monitoring: A new paradigm for lang-term research and monitoring", Trends in Ecology 6 Evolution, 24(9): 482-486, [DOI]. (Cited on page 23.)

Lövei, G.L. and Arpaia, S. (2005), "The impact of transgenic plants on natural enemies: a critical review of laboratory studies", Entomologia Experimentalis et Applicata, 114: 1-14, [DOI]. (Cited on pages 5,6 , and 23.)

Märländer, B. (2005), "Weed control in sugar beet using genetically modified herbicide-tolerant varieties - A review of the economics for cultivation in Europe", Journal of Agronomy and Crop Science, 191: 64-74, [DOI]. (Cited on page 12.)

Märländer, B., Lange, T. and Wulkow, A. (2010), "The biology of sugar beet, particularly with regard to the potential of dispersal. Expertise for the German Federal Agency for Nature Conservation", Bonn (Bundesamt für Naturschutz). (Cited on pages 11 and 12.)

May, M. (2009), "Control of weed beet and bolters", British Sugar Beet Review, 77(2): 34-35. (Cited on pages 10 and 11.)

May, M.J., Champion, G.T., Dewar, A.M., Qi, A. and Pidgeon, J.D. (2005), "Management of genetically modified herbicide-tolerant sugar beet for spring and autumn environmental benefit", Proceedings of the Royal Society of London, Series B: Biological Sciences, 272: 111-119, [DOI]. (Cited on page 15.)

McLaughlin, A. and Mineau, P. (1995), "The impact of agricultural practices on biodiversity", Agriculture, Ecosystems \& Environment, 55: 201-212, [DOI]. (Cited on pages 15 and 17.)

Metzger, M., Bunce, B., Jongman, R., Mücher, S. and Watkins, J.W. (2005), "A climatic stratification of the environment in Europe", Global Ecology and Biogeography, 14: 549, [DOI]. (Cited on page 7. )

Middelhoff, U., Reiche, E.-W. and Windhorst, W. (2010), "An integrative methodology to predict dispersal of genetically modified genotypes in oilseed rape at landscape-level - A study for the region of Schleswig-Holstein, Germany", Ecological Indicators, in press, [DOI]. (Cited on page 6.)

Nielsen, K.M. and Townsend, J.P. (2004), "Monitoring and modelling horizontal gene transfer", Nature Biotechnology, 22: 1110-1114, [DOI]. (Cited on pages 11 and 14.)

OECD (2006), "Safety Assessment of Transgenic Organisms: OECD Consensus Documents, Vols. 1 and 2", Paris (OECD). (Cited on pages 5, 10, 11, and 14.) 
Orson, J. (2002), "Gene stacking in herbicide tolerant oilseed rape: lessons from the North American experience", English Nature research Reports, R443, Sheffield (Natural England). Online version (accessed 04 August 2010):

http://naturalengland.etraderstores.com/NaturalEnglandShop/R443. (Cited on pages 12 and 15.)

Owen, M. (1999), "Weed management update for the next millennium", Ames, IA (Iowa State University). (Cited on page 17.)

Owen, M.D.K. and Zelaya, I.A. (2005), "Herbicide-resistant crops and weed resistance to herbicides", Pest Management Science, 61: 301-311, [DOI]. (Cited on pages 12 and 17.)

Pacini, C., Wossink, A., Giesen, G., Vazzana, C. and Huirne, R. (2003), "Evaluation of sustainability of organic, integrated and conventional farming systems: a farm and field-scale analysis", Agriculture, Ecosystems \& Environment, 95(1): 273-288, [DOI]. (Cited on page 17.)

Perry, J.N., ter Braak, C.J.F. Dixon, P.M., Duan, J.J., Hails, R.S., Huesken, A., Lavielle, M., Marvier, M., Scardi, M., Schmidt, K., Tothmeresz, B., Schaarschmidt, F. and van der Voet, H. (2009), "Statistical aspects of environmental risk assessment of GM plants for effects on non-target organisms", Environmental Biosafety Research, 8: 65, [DOI]. (Cited on pages 5, 6, and 23.)

Pessel, F.D., Lecomte, J., Emeriau, V., Krouti, M., Messan, A. and Gouyon, P.-H. (2001), "Persistence of oilseed rape in natural habitats: consequence for release of transgenic crops", Theoretical and Applied Genetics, 102: 841. (Cited on page 11.)

Popp, M., Hann, S., Mentler, A., Fuerhacker, M., Stingeder, G. and Koellensperger, G. (2008), "Determination of glyphosate and AMPA in surface and waste water using high-performance ion chromatography coupled to inductively coupled plasma dynamic reaction cell mass spectrometry (HPIC-ICP-DRC-MS)", Analytical $\&$ Bioanalytical Chemistry, 1(2): 695-699, [DOI]. (Cited on page 17.)

Regal, P. J. (1994), "Scientific principles for ecologically based risk assessment of transgenic organisms", Molecular Ecology, 3: 5-13, [DOI]. (Cited on pages 6 and 17.)

Relyea, R. (2005a), "The lethal impacts of Roundup on aquatic and terrestrial amphibians", Ecological Applications, 15: 1118-1124, [DOI]. (Cited on pages 5, 14, and 17.)

Relyea, R. (2005b), "The impact of insecticides and herbicides on the biodiversity and productivity of aquatic communities", Ecological Applications, 15: 618-627, [DOI]. (Cited on pages 5, 14, and 17.)

Relyea, R.A. (2005c), "The Lethal Impacts of Roundup and Predatory Stress on Six Species of North American Tadpoles", Archives of Environmental Contamination and Toxicology, 48(3): 351-357, [DOI]. (Cited on pages 5, 14, and 17.)

Rensing, C., Newby, D.T. and Pepper, I.L. (2002), "The role of selective pressure and selfish DNA in horizontal gene transfer and soil microbial community adaptation", Soil Biology 86 Biochemistry, 34: 285-296, [DOI]. (Cited on page 11.)

Reuter, H., Middelhoff, U., Graef, F., Verhoeven, R., Batz, T., Weiss, M., Schmidt, G., Schröder, W. and Breckling, B. (2010a), "Information system for monitoring environmental impacts of genetically modified organisms", Environmental Science and Pollution Research, 17(8): 14791490, [DOI]. (Cited on page 6.) 
Reuter, H., Schmidt, G., Schröder, W., Middelhoff, U., Pehlke, H. and Breckling, B. (2010b), "Regional distribution of genetically modified organisms (GMO) - Up-scaling the dispersal and persistence potential of herbicide resistant oilseed rape (Brassisca napus)", Ecological Indicators, in press, [DOI]. (Cited on page 6.)

Richard, S., Moslemi, S., Sipahutar, H., Benachour, N. and Seralini, G.-E. (2005), "Differential effects of glyphosate and Roundup on human placental cells and aromatase", Environmental Health Perspectives, 113(6), [DOI]. (Cited on page 14.)

Robinson, R.A. and Sutherland, W.J. (2002), "Post-war changes in arable farming and biodiversity in Great Britain", Journal of Applied Ecology, 39: 157-176, [DOI]. (Cited on page 17.)

Römbke, J., Jänsch, S., Meier, M., Hilbeck, A., Teichmann, H. and Tappeser, B. (2010), "General recommendations for soil ecotoxicological tests suitable for the environmental risk assessment of genetically modified plants", Integrated Environmental Assessment and Management, 6(2): 287-300, [DOI]. (Cited on pages 22 and 23.)

Roy, D.B., Bohan, D.A., Haughton, A.J., Hill, M.O., Osborne, J.L., Clark, S.J., Perry, J.N., Rothery, P., Scott, R.J., Brooks, D.R., Champion, G.T., Hawes, C., Heard, M.S. and Firbank, L.G. (2003), "Invertebrates and vegetation of field margins adjacent to crops subject to contrasting herbicide regimes in the Farm Scale Evaluations of genetically modified herbicide-tolerant crops", Philosophical Transactions of the Royal Society of London, Series B, 358: 1879-1898. (Cited on page 5.)

Sanyal, D., Bhowmik, P.C., Anderson, R.L. and Shrestha, A. (2008), "Revisiting the perspective and progress of integrated weed management", Weed Science, 56: 161-167, [DOI]. (Cited on page 17.)

Schiemann, J. (2003), "Co-existence of genetically modified crops with conventional and organic farming", Environmental Biosafety Research, 2(4): 213-217, [DOI]. (Cited on pages 13 and 17.)

Schütte, G. and Mertens, M. (2010), "Potential effects of the introduction of a sugar beet variety resistant to glyphosate on agricultural practice and on the environment", Bonn (Bundesamt für Naturschutz). (Cited on page 12.)

Schütte, G., Stachow, U. and Werner, A. (2004), "Agronomic and environmental aspects of the cultivation of transgenic herbicide resistant plants", 11/2004, Berlin (Umweltbundesamt). Online version (accessed 04 August 2010):

http: //www. umweltbundesamt.de/uba-info-medien/publikationsliste-reihe-drucken. php. (Cited on pages 15 and 17.)

Scientific American eds. (2009), "A Seedy Practice", Scientific American, 301: 28, [DOI]. (Cited on page 23.)

Senior, I.J. and Dale, P.J. (2002), "Herbicide-tolerant crops in agriculture: oilseed rape as a case study", Plant Breeding, 121: 97-107, [DOI]. (Cited on page 12.)

Snow, A.A. (2003), "Consequences of gene flow", Environmental Biosafety Research, 2: 43-46. (Cited on page 14.)

Soukup, J., Holec, J., Vejl, P., Skupinová, S. and Sedlák, P. (2002), "Diversity and distribution of weed beet in the Czech Republic", Journal of Plant Diseases and Protection, Sonderheft XVII: 67-74. (Cited on page 11.)

Living Reviews in Landscape Research

http://www. livingreviews . org/lrlr-2010-3 
Squire, G.R., Brooks, D.R., Bohan, D.A., Champion, G.T., Daniels, R.E., Haughton, A.J., Hawes, C., Heard, M.S., Hill, M.O., May, M.J., Osborne, J.L., Perry, J.N., Roy, D.B., Woiwod, I.P. and Firbank, L.G. (2003), "On the rationale and interpretation of the Farm Scale Evaluations of genetically modified herbicide-tolerant crops", Philosophical Transactions of the Royal Society of London, Series B, 358: 1779-1799. (Cited on pages 14, 15, and 17.)

Squire, G.R., Hawes, C., Begg, G.S. and Young, M.W. (2009), "Cumulative impact of GM herbicide-tolerratn cropping on arable plants assessed through species-based and functional taxonomies", Environmental Science and Pollution Research, 16: 85-94, [DOI]. (Cited on pages 6 and 23.)

Stein, A. and Ettema, C. (2003), "An overview of spatial sampling procedures and experimental design of spatial studies for ecosystem comparisons", Agriculture, Ecosystems $\&$ Environment, 94: 31, [DOI]. (Cited on pages 9 and 23.)

Strandberg, B., Bruus Pedersen, M. and Elmegaard, N. (2005), "Weed and arthropod populations in conventional and genetically modified herbicide tolerant fodder beet fields", Agriculture, Ecosystems 83 Environment, 105: 243-253, [DOI]. (Cited on pages 15 and 17.)

Sukopp, U., Pohl, M., Driessen, S. and Bartsch, D. (2005), "Feral Beets - With Help from the Maritime Wild?", in Gressel, J., ed., Crop Ferality and Volunteerism, pp. 45-57, Boca Raton, FL (CRC Press). Google Books. (Cited on pages 5, 11, and 14.)

Tesfamariam, T., Bott, S., Cakmak, I., Romheld, V. and Neumann, G. (2009), "Glyphosate in the rhizosphere - Role of waiting times and different glyphosate binding forms in soils for phytotoxicity to non-target plants", European Journal of Agronomy, 31(3): 126-132, [DOI]. (Cited on pages 14 and 17.)

Thorbek, P. and Bilde, T. (2004), "Reduced numbers of generalist arthropod predators after crop management", Journal of Applied Ecology, 41: 526-538, [DOI]. (Cited on pages 12, 15, and 17.)

Van Acker, R.C., Brûlé-Babel, A.L. and Friesen, L.F. (2003), "An Environmental Safety Assessment of Roundup Ready Wheat: Risks for Direct Seeding Systems in Western Canada", Winnipeg (Canadian Wheat Board). (Cited on pages 15 and 17.)

Van Geyt, J.P.C., Lange, W., Oleo, M. and De Bock, T.S.M. (1990), "Natural variation within the genus Beta and its possible use for breeding sugar beet: a review", Euphytica, 49: 57. (Cited on pages 10 and 11.)

Viard, F., Bernard, J. and Desplanque, B. (2002), "Crop-weed interactions in the Beta vulgaris complex at a local scale: allelic diversity and gene flow within sugar beet fields", Theoretical and Applied Genetics, 104: 688, [DOI]. (Cited on pages 11 and 12.)

Waltz, E. (2009), "Under wraps", Nature Biotechnology, 27: 880-883, [DOI]. (Cited on page 23.)

Watkinson, A.R., Freckleton, R.P., Robinson, R.A. and Sutherland, W-.J. (2000), "Predictions of biodiversity response to genetically modified herbicide-tolerant crops", Science, 289: 1554, [DOI]. (Cited on pages 11, 14, and 17.)

Werner, A., Berger, G., Stachow, U. and Glemnitz, M. (2000), "Abschätzung der Auswirkungen transgener Sorten auf Umweltqualitätsziele (TA-Projekt Nachhaltige Landwirtschaft 19971999)", Basel (BATS). Online version (accessed 04 August 2010):

http://www.bats.ch/bats/publikationen/nachhaltige_landwirtschaft/nachhaltige_ landwirtschaft4-6.pdf. (Cited on pages 15 and 17.) 
Wilkinson, M.J., Davenport, I.J., Charters, Y.M., Jones, A.E., Allainguillaume, J., Butler, H.T., Mason, D.C. and Raybould, A.F. (2000), "A direct regional scale estimate of transgene movement from genetically modified oil-seed rape to its wild progenitors", Molecular Ecology, 9: 983-991, [DOI]. (Cited on page 14.)

Wilkinson, M.J., Sweet, J. and Poppy, G.M. (2003), "Risk assessment of GM plants: avoiding gridlock?", Trends in Plant Science, 8(5): 208, [DOI]. (Cited on page 5.)

Zelaya, I.A., Owen, M.D.K. and VanGessel, M.J. (2007), "Transfer of glyphosate resistance: evidence of hybridization in Conyza (Asteraceae)", American Journal of Botany, 94: 660-673, [DOI]. (Cited on page 5.)

Zeller, S.L., Kalinina, O., Brunner, S., Keller, B. and Schmid, B. (2010), "Transgene × Environment Interactions in Genetically Modified Wheat", PLoS ONE, 5(7), e11405, [DOI]. (Cited on page 14.)

Zobiole, L.H.S., Oliveira Jr, R.S., Visentainer, J.V., Kremer, R.J., Bellaloui, N. and Yamada, T. (2010), "Glyphosate affects seed composition in glyphosate-resistant soybean", Journal of Agricultural and Food Chemistry, 58(7): 4517-4522, [DOI]. (Cited on page 17.)

Züghart, W. and Breckling, B. (2003), "Konzeptionelle Entwicklung eines Monitoring von Umweltwirkungen transgener Kulturpflanzen, Teil 1 und 2", 50/2003, Berlin (Umweltbundesamt). Online version (accessed 04 August 2010):

http: //www . umweltbundesamt.de/uba-info-medien/publikationsliste-reihe-drucken. php. (Cited on pages 11, 14, 15, and 17.)

Züghart, W., Benzler, A., Berhorn, F., Sukopp, U. and Graef, F. (2008), "Determining indicators, methods and sites for monitoring potential adverse effects of genetically modified plants to the environment: the legal and conceptional framework for implementation", Euphytica, 164(3): 845-852, [DOI]. (Cited on pages 5, 6, 8, and 23.) 